\title{
Gut Microbiota and Cancer: From Pathogenesis to Therapy
}

\author{
Silvia Vivarelli ${ }^{1}$ (D), Rossella Salemi ${ }^{1}$, Saverio Candido ${ }^{1}$, Luca Falzone ${ }^{1}$, Maria Santagati ${ }^{2}$ (D), \\ Stefania Stefani $^{2} \mathbb{D}$, Francesco Torino ${ }^{3}$, Giuseppe Luigi Banna ${ }^{4}$, Giuseppe Tonini ${ }^{5}$ and \\ Massimo Libra ${ }^{1,6, *}$
}

1 Department of Biomedical and Biotechnological Sciences, Oncologic, Clinic and General Pathology Section, University of Catania, 95123 Catania, Italy; silvia.vivarelli7@gmail.com (S.V.); rossellasalemi@alice.it (R.S.); scandido@unict.it (S.C.); luca.falzone@unict.it (L.F.)

2 Department of Biomedical and Biotechnological Sciences, Section of Microbiology, University of Catania, 95123 Catania, Italy; m.santagati@unict.it (M.S.); stefanis@unict.it (S.S.)

3 Department of Systems Medicine, Medical Oncology, Tor Vergata University of Rome, 00133 Rome, Italy; torino@med.uniroma2.it

4 Division of Medical Oncology, Cannizzaro Hospital, 95126 Catania, Italy; gbanna@yahoo.com

5 Department of Medical Oncology, University Campus Bio-Medico of Rome, 00128 Rome, Italy; G.Tonini@unicampus.it

6 Research Center for Prevention, Diagnosis and Treatment of Cancer, University of Catania, 95123 Catania, Italy

* Correspondence: mlibra@unict.it; Tel.: +39-095-478-1271

Received: 14 December 2018; Accepted: 27 December 2018; Published: 3 January 2019

\begin{abstract}
Cancer is a multifactorial pathology and it represents the second leading cause of death worldwide. In the recent years, numerous studies highlighted the dual role of the gut microbiota in preserving host's health. Gut resident bacteria are able to produce a number of metabolites and bioproducts necessary to protect host's and gut's homeostasis. Conversely, several microbiota subpopulations may expand during pathological dysbiosis and therefore produce high levels of toxins capable, in turn, to trigger both inflammation and tumorigenesis. Importantly, gut microbiota can interact with the host either modulating directly the gut epithelium or the immune system. Numerous gut populating bacteria, called probiotics, have been identified as protective against the genesis of tumors. Given their capability of preserving gut homeostasis, probiotics are currently tested to help to fight dysbiosis in cancer patients subjected to chemotherapy and radiotherapy. Most recently, three independent studies show that specific gut resident species may potentiate the positive outcome of anti-cancer immunotherapy. The highly significant studies, uncovering the tight association between gut microbiota and tumorigenesis, as well as gut microbiota and anti-cancer therapy, are here described. The role of the Lactobacillus rhamnosus GG (LGG), as the most studied probiotic model in cancer, is also reported. Overall, according to the findings here summarized, novel strategies integrating probiotics, such as LGG, with conventional anti-cancer therapies are strongly encouraged.
\end{abstract}

Keywords: microbiota; microbiome; cancer; anti-cancer therapy; integrated therapy; inflammasomes; probiotics; Lactobacillus rhamnosus GG

\section{Introduction}

Cancer is the second leading cause of death worldwide [1,2]. Cancer formation is the result of the stochastic intracellular accumulation of spontaneous mutations during DNA replication, combined with the environment exposure and lifestyle habits, both able to significantly influence cancer risk $[3,4]$. 
For example, the exposure to infectious agents, UV radiation and toxic substances, individual diet and lifestyle, strongly influences cancer rise, although the risk mainly depends on the dose, the duration and the combination of such injuries, coupled with the individual genetic background [5].

In the recent years, numerous evidences pointed towards the central role of commensal bacteria colonizing body surfaces as key determinants of health or pathologic conditions, including cancer [6]. Among the human symbiotic microbial populations, the gut microbiota is the most extensively studied and it deeply influences host's homeostasis [7]. Gut microbiota is the name given to the heterogeneous population of commensal microorganisms, mainly bacteria, but also fungi, archaea and viruses, populating the intestinal tract, mostly the large intestine, and it can be considered as one factor to which we are persistently exposed, at high doses, throughout the entire lifespan [8]. Among a 1000 of different bacterial species within the gut microbiota, the highly represented ones are the Firmicutes and Bacteroidetes phyla [9]. The gut microbiota performs a number of vital functions, including production of vitamins, metabolization of dietary compounds, protection against the expansion and systemic infiltration of gut pathogens [10-12]. The gut microbial balance has a key role in the correct fulfilment of all these pivotal metabolic functions. Any imbalance in this delicate equilibrium may lead to an impaired microbiota, condition called dysbiosis, linked with several human pathologies, including cancer [13].

The gut microbiome, defined as the whole genome of the host's gut microbiota, encodes 100 -fold more genes than the human genome [14]. Within the last decade, the advent of metagenomics, combining next-generation sequencing (NGS) with computational analysis of the 16S rRNA amplicons, allowed to characterize both diversity and abundance of the gut microbiome. Progresses in metagenomics studies, together with the advancements in transcriptomics and metabolomics, allowed to describe the impact of individual bacterial species on host's health $[15,16]$. That represents a step forward, from descriptive microbiome composition analyses, to functional studies, which are nowadays helping to understand the true impact of the microbiome architecture on human health $[17,18]$. However, this research is at its beginning, and all these growing number of associative and functional studies need to be further corroborated by results obtained from larger clinical studies [19].

Among all the pathologies linked with the gut microbiome, tumorigenesis is one of the mostly studied. The link has been found both with local gastro-intestinal cancers, as well as with other distal tumors [20]. Metabolomics and metagenomics studies highlighted the dual role of the gastro-intestinal microbiome in cancer prevention, tumorigenesis and anti-cancer therapy [21]. In fact, the gut microbiome can either be tumor-suppressive or oncogenic [22,23]. Although this link is studied since long ago, it is only partially characterized. In fact, all the current knowledge emphasizes the complexity and bidirectionality of the connection existing between microbiome and cancer. As a consequence, cancer development may alter the microbiome and, in turn, microbiome changes may affect cancer progression [24].

In this review, the up-to-date studies uncovering the tight link between gut microbiota and tumorigenesis will be described. Moreover, the importance of probiotics supplementation with anti-cancer therapy will be also discussed, including the key role and the future applications of a probiotic model studied in cancer, Lactobacillus rhamnosus GG (LGG), often used to treat cancer patients' intestinal dysbiosis.

\section{Gut Microbiota and Host's Tumorigenesis}

\subsection{Gut Microbiota and Host Crosstalk}

The gut is bidirectionally connected with the nervous system through the so-called "gut-brain axis" (GBA), which includes the central nervous system (CNS), the autonomic nervous system (ANS), the enteric nervous system (ENS), the hypothalamic pituitary adrenal (HPA) axis and the 
entero-endocrine system (EES). Hormones and neuro-hormones secreted at each of these listed GBA levels may modulate the gastro-intestinal digestive and metabolic activities, and vice-versa [25].

For that reason, the gut represents a complex interface between the gastro-intestinal resident microbiota and the human body. There is a bidirectional crosstalk between gut resident microbes and host's GBA, in which the gut functions as the communication gatekeeper [26]. In particular, it is known that host's hormones and neuro-hormones are able to modify the gut microbiome composition, as during stress response [27]. Importantly, the gastro-intestinal entero-endocrine cells secrete over 30 different peptide hormones, involved in several functions, such as gastro-intestinal motility, digestive functions and neuromodulation [28]. A number of these hormones can be sensed by the gut bacteria, as in the case of leptin and ghrelin, which, in turn, finely tune the gut microbiota composition in rodents $[29,30]$.

In the same way, the gut microbial population secrete active molecules which can be sensed by the gut cells and whose effects are then transduced to the GBA [27]. In fact, it has been widely studied that the gut microbiota may produce or transform molecules affecting several aspects of human health, including: host's metabolism modulation, gut barrier integrity maintenance, xenobiotics and drug metabolism, protection against gastro-intestinal pathogens and host's immune system modulation [31-34].

With regards to the host's metabolism, it is known that certain commensal bacteria produce essential micronutrients, such as vitamin $\mathrm{K}$ and various components of vitamin $\mathrm{B}$. Also, members of the Bacterioides family are able to synthetize the anti-diabetic compound linoleic acid, to catabolize secondary bile acids and to break down phenolic compounds. Moreover, a number of gut commensals can modify small aminoacids into signaling molecules, as for example histidine to histamine or glutamate to $\gamma$-aminobutyric acid (GABA) [35].

Additionally, it has been reported that gut resident commensals can produce hormone-like metabolites, such as the short chain fatty acids (SCFAs), as a consequence of the bacterial fermentation of dietary fibers in the large intestine [36]. The nature of the SCFAs synthetized depends on both diet and microbiota specific composition. The SCFAs, once produced by the gut bacteria, are transported through the bloodstream, and used by the liver as the main source of energy. Importantly, SCFAs have a role in controlling the glucose and the lipidic metabolism, by affecting the intestine hormone peptide secretion, including Peptide YY (PYY) and Glucagon-like peptide 1 (GLP-1) [37].

\subsection{Gut Microbiota as a Tumor-Suppressor}

Given the above illustrated complex crosstalk occurring between the host and its gut microbiota, it is not surprising that the gut microbial population may affect pathological processes, such as cancer genesis and development, either in a positive or in a negative way, depending on its own composition. Remarkably, a number of microbes-derived molecules show an anti-tumor activity.

In particular, microbial-derived SCFAs may have an anti-cancer effect. For example, gut bacterial butyrate and propionate are able to inhibit host's tumor cells histone deacetylases with a general anti-cancer effect. Such mechanism is the cause of the anti-tumoral in vitro and in vivo effect of butyrate observed in both colorectal cancer (CRC) and lymphoma [38,39]. Some of the probiotics' derived molecules and metabolites are able to modulate host's immune system, thereby triggering an indirect immune-mediated response against tumor development. For example, the widely studied bacterial lipopolysaccharide (LPS), a major component of the outer membrane in gram-negative bacteria, activates the host's cell surface receptor toll-like receptor 4 (TLR4), belonging to the family of pattern recognition receptors (PRRs), thus activating immune T cell-mediated response against cancer cells [40]. In the same way, the monophosphoryl lipid A (MPL) from Salmonella enterica has been currently used as adjuvant in the vaccine formulation used against anti-cervical carcinoma [41]. Moreover, bacterial derived pyridoxine, a group B vitamin, can stimulate host's antitumoral immunosurveillance [42].

Several commensal bacteria play a probiotic role thanks to their capability to confer health benefits, either protecting against gut dysbiosis or enhancing host's immune defense mechanisms [22,24]. 
The administration of such probiotics, as for example Mutaflor (Escherichia coli Nissle 1917) combined with the intestinal antibiotic rifaximin, demonstrated a clear anti-inflammatory activity, enhancing the anti-inflammatory effect of rifaximin in a rat model of inflammatory bowel disease [43]. Additionally, many probiotics have shown a potential antineoplastic activity. For example, probiotics or probiotics-derived metabolites administered to mice can, in turn, to inhibit tumor growth. One good example is ferricrome metabolite secreted from Lactobacillus casei, able to trigger apoptosis in tumor cells via JNK pathway direct activation [44]. It has been also reported in several studies that Lactobacilli may stimulate host's immune cells such as NK cells or dendritic cells (DC) or TH1 response, which, in turn, leads to the elimination of cancerous or precancerous cells, although the exact bacterial bioproduct mediating such stimulatory effect still needs to be identified [45-48]. A summary of the gut microbiome anti-cancer functions is illustrated in Figure 1.

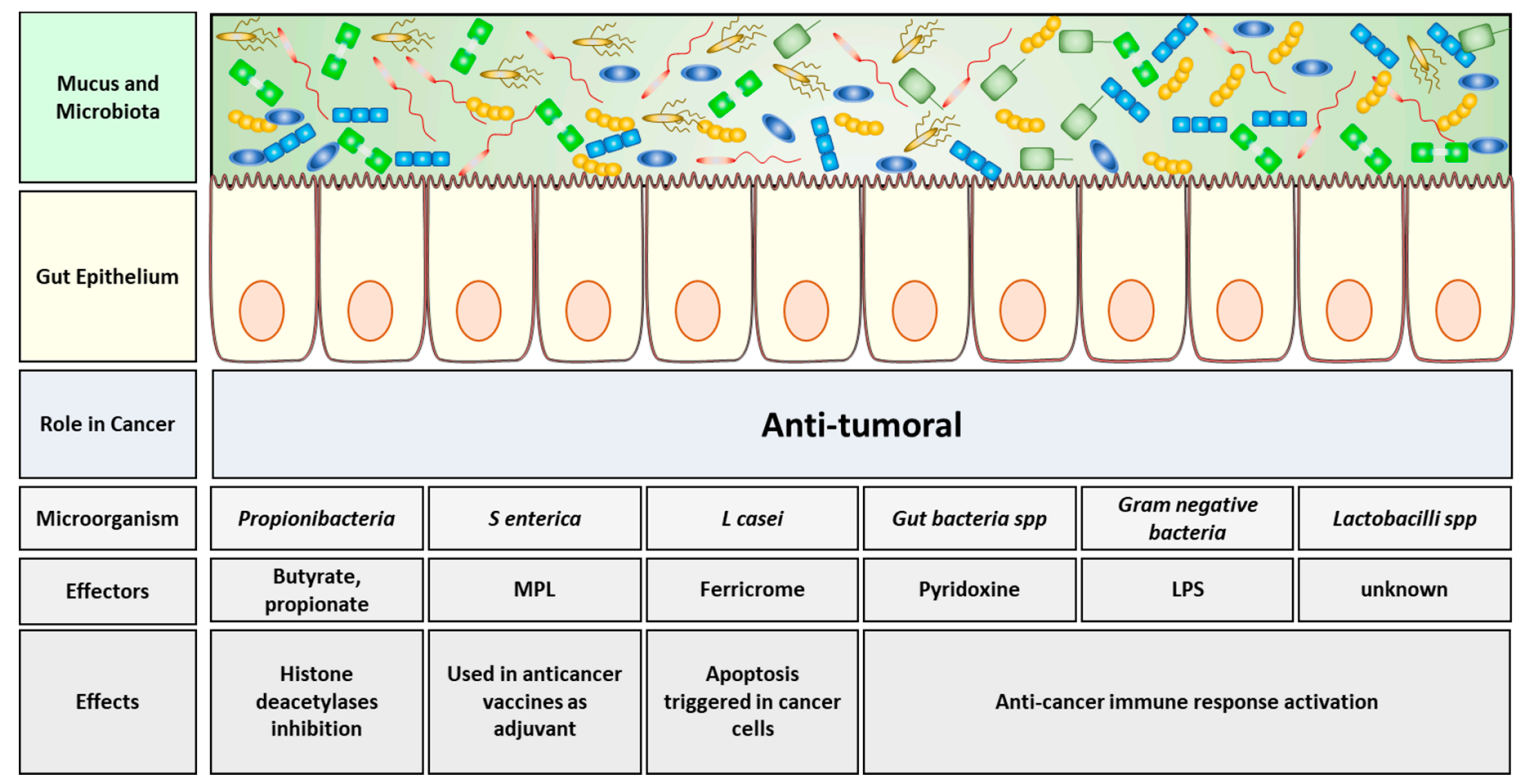

Figure 1. Anti-tumoral effects of the gut microbiota. Probiotics and other gut resident bacteria are able to secrete molecules, capable, in turn, to fight tumor growth and prevent tumorigenesis through several mechanisms. Schematic of the intestinal layers, from top to bottom: mucus and microbiota, gut epithelium. Into the grey boxes are illustrated, from top to bottom, the microorganism species implicated in the anti-cancer process, the molecules produced and the corresponding effects induced within the host. Abbreviations: MPL, monophosphoryl lipid A; LPS, lipopolysaccharide.

\subsection{Gut Microbiota as a Tumor-Promoter}

Gut dysbiosis and the consequent development of pathogenic populations within the gut microbiota, may contribute to a wide variety of pathologies, even in sites distant from the gut, ranging from bowel inflammation, to neurodegenerative diseases (including Parkinson's disease) and cancer $[43,49,50]$.

Regarding cancer, within a dysbiotic gut, certain bacterial pathogens can negatively affect either the host's metabolism or the host's gut and immune system functionalities, thereby triggering tumor growth [51]. Importantly, gastro-intestinal dysbiosis has been linked with both local and distant tumors [52]. Microbial pathogens are known to drive the $20 \%$ of tumorigenesis and a larger number of malignancies are associated with microbial commensal imbalance, or dysbiosis [53]. In line with that, many preclinical studies performed using germ-free mice models demonstrated how the gut microbiome is able to deeply affect cancer genesis and progression through different mechanisms [33,54,55].

Helicobacter pylori produced protein CagA was the first bacterial protein shown to be involved in human cancer [56]. Although only Helicobacter pylori is included among class I carcinogens by 
the World Health Organization (WHO) [57], several studies performed in cell culture and animal models, assessed the ability of additional microbiota populations to affect host's DNA replication and integrity [58-60]. In fact, during pathogenic infections, when the gut microbiome is affected by dysbiosis, bacterial pathogens can expand and release a large amount of toxins which, in turn, induce host's DNA breaks, thus contributing to genomic instability, tumor initiation and progression in those predisposed cells [61-63]. This is the case of colibactin and cytolethal distending toxin (CDT) both produced by Escherichia coli and displaying a DNAse activity. Once released in the proximity of the gastrointestinal epithelium, the toxins generate DNA double-strand breaks within the host's epithelial cells, thus promoting a transient cell cycle arrest, allowing for genomic mutations to arise, and finally leading to tumor formation [64]. Gut pathogenic bacteria can also interfere with DNA damage response and repair pathways, as in the case of Shigella flexneri, inducing host's cells p53 degradation via the secretion of its enzymes inositol phosphate phosphatase $\mathrm{D}(\mathrm{IpgD})$ and cysteine protease-like virulence gene A (VirA), therefore increasing the probability of introducing mutations during the DNA damage response in infected cells [65]. In the same way, the product of the cytotoxin associated gene A (CagA) from Helicobacter pylori, induces the proteasome-mediated degradation of p53 in gastric epithelial cells, by interfering with the host's AKT pathway, thus promoting the rise of gastric cancer [66].

Moreover, gut bacteria can modulate several host's cellular proliferative and pro-survival pathways, therefore contributing to cancer. For example, Helicobacter pylori derived CagA protein, Fusobacterium nucleatum effector adhesin A (FadA) and Bacteroides fragilis metalloproteinase toxin (MP toxin) are all capable to interact (directly or indirectly) with the host's epithelial E-cadherin, thus disrupting the intercellular junctions and activating $\beta$-catenin signaling. This, in turn, triggers cell proliferation and the potential cancerogenic transformation of those affected host's cells [67-69]. In the same direction, the Salmonella enterica effector avirulence protein A (AvrA) is able to translocate into host's cells and activate $\beta$-catenin via its intrinsic de-ubiquitinase activity [70].

As for the $\beta$-catenin signaling, other virulence factors released in the extracellular gut milieu during a pathogenic infection, can potentially induce cancer transformation when infecting pre-transformed cells, through the activation of other pro-survival intrinsic host's cellular pathways, such as MAPK and AKT, as for CagA from Helicobacter pylori, controlling the hosts MAPK pathway or AvrA from Salmonella enterica, triggering both MAPK and AKT pathways [71,72]. In particular, CagA from Helicobacter pylori can bind many host's proteins intracellularly, including the protein tyrosine phosphatase SHP-2. CagA-SHP-2 complex formation deregulates the phosphatase activity of SHP-2, which, in turn, promotes Ras/MAPK signaling activation [73].

Additionally, pathogenic bacteria may indirectly affect host's tumorigenesis. Different mechanisms can mediate this effect. One is the generation of oxidative stress, leading to cell autonomous genomic mutations [74,75]. Another one consists either in the enhancement of the inflammation or the inhibition of the host's immune response, thus helping the tumor immune-escape [76]. For example, Helicobacter pylori or Bacteroides fragilis are both able to activate the host's spermine oxidase, which, in turn, generates hydrogen peroxide and reactive oxygen species (ROS)-induced accumulation of DNA damage [77,78]. Enterococcus faecalis produces extracellular superoxide and derivative oxygen species is capable to diffuse into host's cells. In turn, the increase in the oxidative milieu enhances the possibility of host's cellular DNA mutations [79].

Moreover, relevant bacteria can stimulate cancer formation by blocking immune-effectors that normally inhibit tumorigenesis. For example, Fusobacterium nucleatum inhibits for its own advantage host's Natural Killer (NK) cells, in order to recruit at the site of the infection myeloid suppressor cells, therefore indirectly helping cancer genesis. Such mechanism is mediated by the bacterial virulence factor Fap2, able to bind and block the NK inhibitory receptor TGIT, thus arresting the NK-mediated tumor cell attack [80].

Finally, certain microbiota species may interfere with host's hormones metabolism. In fact, it has been widely studied the link between bacterial secretion of the $\beta$-glucuronidase enzymes and the 
increased bioavailability of the host's estrogen hormones (both originating from hepatic catabolism and phytoestrogens). When gut dysbiosis is coupled with an increase in the $\beta$-glucuronidase-secreting bacteria, such as Clostridium leptum and Clostridium coccoides, the enzyme deconjugates liver-catabolized and plant-derived estrogens, enabling them to bind and activate the estrogen receptors expressed by target cells [81]. Estrogen receptors activation promotes cell proliferation in tissues responding to estrogens, as breast and endometrium [82]. Accordingly, this augmented intake of estrogen hormones is linked with an increased risk of developing breast cancer, supporting the finding that the gut microbiota composition of women with breast cancer differs from that from healthy controls, and suggesting that several gut bacteria, which could be over-expressed during dysbiosis, may be linked with breast cancer development [83].

Although there are notable examples of pathogenic microbiota capable of promoting oncogenesis through the modulation oncogenic host's cell pathways or by interfering either with the host's hormonal or the host's immune system, no strong bacterial oncogenic driver has been identified yet. In particular, it is difficult to clearly determine whether microbiota changes might affect cancer genesis or the contrary [84]. Additionally, changes in the host's lifestyle, diet and immune system are among the factors which deeply influence the microbiota composition and activity [85]. Moreover, the very same anti-cancer treatment might shape the patient's microbiome and, at the same time, host's specific microbiome can deeply affect patient's response to therapy [19]. A summary of the gut bacteria pro-tumoral functions is schematized in Figure 2.

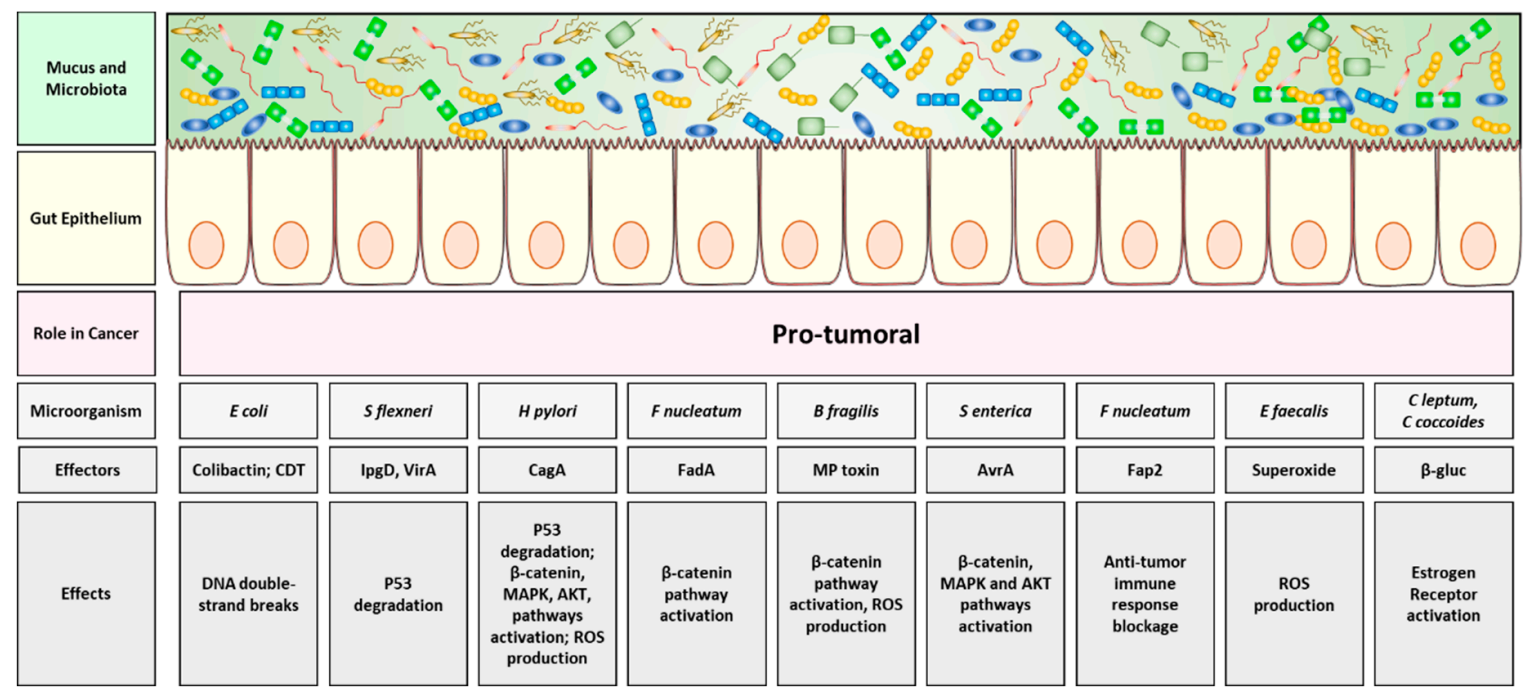

Figure 2. Pro-tumoral effects of the gut microbiota. Bacteria prominent during gut dysbiosis can secrete toxins able to interfere with host cell growth, finally predisposing the host organism to cancer development. Schematic of the intestinal layers, from top to bottom: mucus and microbiota, gut epithelium. Into the grey boxes are illustrated, from top to bottom, the microorganism species implicated in the pro-cancer process, the molecules produced and the corresponding effects induced within the host. Abbreviations: ROS, Reactive Oxygen Species; CTD, cytolethal distending toxin; IpgD, inositol phosphate phosphatase D; VirA, virulence gene A; CagA, cytotoxin associated gene A; FadA, Fusobacterium effector adhesin A; MP Toxin, metalloproteinase toxin; AvrA, avirulence protein A; $\beta$-gluc, $\beta$-glucuronidase.

\section{Lactobacillus rhamnosus GG: A Probiotic Model in Cancer}

Due to its anti-inflammatory properties, the probiotic archetype Lactobacillus rhamnosus GG (LGG) is one of the most studied and well characterized among probiotics. The probiotics, including Lactobacilli, are studied as supportive treatment for chemotherapy-associated gastrointestinal toxicity, thanks to their ability to restore gut microbial balance, as further described in Section 5 [86]. Among these probiotic species, LGG is one of the first studied specifically in oncology [87]. LGG is 
a gut resident bacterium known to have several anti-inflammatory effects within the intestinal microenvironment [88-90]. In animal models, LGG administered with food attenuates 5-FU-mediated as well as radiation-mediated gut epithelial injury, therefore helping the preservation of the gut microbiota balance and the intestinal epithelial barrier functionality [91-93].

Several potential benefits of LGG administration to cancer patients have been foregrounded since long time, by in vitro, in vivo and clinical studies, as recently reviewed by Banna et al. [94]. In line with these studies, a number of ongoing clinical trials are currently focused on establishing the role of LGG administration in preventing or ameliorating the toxic effects of anti-cancer therapies (Table 1). Additionally, two clinical trials have been designed by our research team and approved by the local ethical committees; while the ClinicalTrials.gov identifiers (NCT numbers) are on their way to be assigned. The two studies are entitled respectively: "Maintenance of normal gastro-intestinal function with dietary supplement containing Lactobacillus rhamnosus GG in cancer patients treated with cytotoxic chemotherapy and/or targeted therapy" and "Maintenance of normal gastro-intestinal function with dietary supplement containing Lactobacillus rhamnosus GG in patients treated with abdominal or pelvic radiotherapy". The two trials are aimed to assess the efficacy of LGG daily oral administration in the maintenance of normal gastro-intestinal functions in cancer patients treated either with chemotherapy and/or targeted therapy or abdominal/pelvic radiotherapy. In addition, the effects of such dietary supplementation on both the patients' intestinal microbiome composition and also in their circulating microRNAs pattern will be further evaluated.

Table 1. Clinical trials * describing the efficacy of probiotics dietary supplementation and/or FMT in cancer patients.

\begin{tabular}{|c|c|c|c|c|c|}
\hline $\begin{array}{l}\text { ClinicalTrials. } \\
\text { Gov Identifier }\end{array}$ & Status & Title & Intervention & Disease & Ref. \\
\hline NCT00936572 & $\mathrm{C}$ & Probiotics in CRC patients & DS: probiotic La1 & CRC & [95] \\
\hline NCT01839721 & $\mathrm{C}$ & $\begin{array}{l}\text { Impact of probiotics on diarrhea in patients } \\
\text { treated with pelvic radiation }\end{array}$ & $\begin{array}{l}\text { DS: probiotic } \\
\text { Bifilact }\end{array}$ & $\begin{array}{l}\text { Various } \\
\text { Cancers }\end{array}$ & [96] \\
\hline NCT01410955 & $\mathrm{C}$ & $\begin{array}{l}\text { Prevention of irinotecan-induced diarrhea } \\
\text { by probiotics }\end{array}$ & $\begin{array}{l}\text { DS: probiotic Colon } \\
\text { Dophilus }\end{array}$ & CRC & [97] \\
\hline NCT01479907 & $\mathrm{C}$ & $\begin{array}{l}\text { Synbiotics and GI function-related quality } \\
\text { of life after colectomy for cancer }\end{array}$ & $\begin{array}{l}\text { DS: prebiotics and } \\
\text { probiotics Synbiotic } \\
\text { Forte }\end{array}$ & CRC & [98] \\
\hline NCT01609660 & $\mathrm{C}$ & $\begin{array}{l}\text { Impact of probiotics on the intestinal } \\
\text { microbiota }\end{array}$ & DS: $S$ boulardii & CRC & [99] \\
\hline NCT03072641 & $\mathrm{C}$ & $\begin{array}{l}\text { Using probiotics to reactivate } \\
\text { tumor-suppressor genes in CRC }\end{array}$ & $\begin{array}{l}\text { DS: probiotic } \\
\text { ProBion Clinica }\end{array}$ & $\mathrm{CC}$ & [100] \\
\hline NCT01468779 & $\mathrm{C}$ & $\begin{array}{l}\text { Effect of probiotics in patients undergoing } \\
\text { surgery for periampullary neoplasms }\end{array}$ & DS: probiotics & PC & [101] \\
\hline NCT01895530 & $\mathrm{C}$ & $\begin{array}{l}\text { Impact of probiotics in modulation of } \\
\text { intestinal microbiota }\end{array}$ & DS: $S$ boulardii & CRC & - \\
\hline NCT03420443 & $\mathrm{C}$ & $\begin{array}{l}\text { Action of synbiotics on irradiated GI } \\
\text { mucosa in RC treatment (FIPIREX) }\end{array}$ & DS: probiotics & $\mathrm{RC}$ & - \\
\hline NCT02771470 & $\mathrm{C}$ & $\begin{array}{l}\text { Intestinal microbiota in lung cancer after } \\
\text { chemotherapy }\end{array}$ & DS: probiotics & $\mathrm{LC}$ & - \\
\hline NCT02021253 & $\mathrm{C}$ & $\begin{array}{l}\text { Influence of probiotics administration } \\
\text { before liver resection in liver disease } \\
\text { (LIPROCES) }\end{array}$ & DS: probiotics & $\mathrm{HCC}$ & - \\
\hline NCT02751736 & $\mathrm{O}$ & $\begin{array}{l}\text { The effect of probiotics on bowel function } \\
\text { restoration after ileostomy closure in } \\
\text { patients with RC }\end{array}$ & $\begin{array}{l}\text { DS: probiotic } \\
\text { CJLP243 }\end{array}$ & $\mathrm{RC}$ & - \\
\hline NCT03290651 & $\mathrm{O}$ & Probiotics and breast health & $\begin{array}{l}\text { DS: probiotic } \\
\text { RepHresh Pro-B }\end{array}$ & $\mathrm{BC}$ & - \\
\hline NCT03518268 & $\mathrm{O}$ & $\begin{array}{l}\text { Vivomixx for prevention of bone loss in } \\
\text { women with BC treated with an aromatase } \\
\text { inhibitor }\end{array}$ & $\begin{array}{l}\text { DS: probiotic } \\
\text { Vivomixx }\end{array}$ & $\mathrm{BC}$ & - \\
\hline NCT03177681 & $\mathrm{O}$ & $\begin{array}{l}\text { The effect of yogurt in cancer patient with } \\
\text { moderate GI symptoms }\end{array}$ & $\begin{array}{l}\text { DS: probiotics in } \\
\text { yogurt }\end{array}$ & $\begin{array}{l}\text { Various } \\
\text { Cancers }\end{array}$ & - \\
\hline
\end{tabular}


Table 1. Cont.

\begin{tabular}{|c|c|c|c|c|c|}
\hline $\begin{array}{l}\text { ClinicalTrials. } \\
\text { Gov Identifier }\end{array}$ & Status & Title & Intervention & Disease & Ref. \\
\hline NCT03642548 & $\mathrm{O}$ & $\begin{array}{l}\text { Probiotics combined with chemotherapy } \\
\text { for patients with advanced NSCLC }\end{array}$ & $\begin{array}{l}\text { Drug with DS of } \\
\text { probiotic Bifico }\end{array}$ & NSCLC & - \\
\hline NCT03358511 & $\mathrm{O}$ & Engineering gut microbiome to target $B C$ & $\begin{array}{l}\text { DS: Probiotic } \\
\text { Primal Defense Ultra }\end{array}$ & $\mathrm{BC}$ & - \\
\hline NCT02944617 & $\mathrm{O}$ & $\begin{array}{l}\text { Probiotic yogurt supplement in reducing } \\
\text { diarrhea in patients with metastatic kidney } \\
\text { cancer being treated with VEGF-TK } \\
\text { inhibitor }\end{array}$ & $\begin{array}{l}\text { DS: probiotics in } \\
\text { yogurt }\end{array}$ & $\begin{array}{l}\text { Renal Cell } \\
\text { Cancer }\end{array}$ & - \\
\hline NCT02351089 & $\mathrm{O}$ & $\begin{array}{l}\text { Probiotics in radiation-treated gynecologic } \\
\text { cancer (ProRad) }\end{array}$ & DS: probiotics & $\begin{array}{l}\text { Gynecologic } \\
\text { Cancer }\end{array}$ & - \\
\hline NCT03574051 & $\mathrm{O}$ & $\begin{array}{l}\text { Microbiota are associated with Iodine-131 } \\
\text { therapy and hypothyroidism }\end{array}$ & $\begin{array}{l}\text { Iodine-131 Therapy } \\
\text { with DS of } \\
\text { probiotics }\end{array}$ & $\begin{array}{l}\text { Thyroid } \\
\text { Cancer }\end{array}$ & - \\
\hline NCT03552458 & $\mathrm{O}$ & $\begin{array}{l}\text { Effects of Probiotics in preventing oral } \\
\text { mucositis in patients undergoing head and } \\
\text { neck radiotherapy }\end{array}$ & $\begin{array}{l}\text { DS: probiotic } L \\
\text { Reuteri }\end{array}$ & $\begin{array}{l}\text { Head-and-neck } \\
\text { Cancer }\end{array}$ & - \\
\hline NCT02819960 & $\mathrm{O}$ & $\begin{array}{l}\text { prevention of irinotecan-induced diarrhea } \\
\text { by probiotics }\end{array}$ & $\begin{array}{l}\text { DS: probiotic } \\
\text { Probio-Fixinum } \\
\text { (including LGG) }\end{array}$ & CRC & - \\
\hline NCT01790035 & $\mathrm{O}$ & $\begin{array}{l}\text { Probiotic LGG for prevention of side-effects } \\
\text { in patients undergoing chemoradiation for } \\
\text { GI cancer }\end{array}$ & DS: probiotic LGG & GI Cancer & - \\
\hline NCT00197873 & $\mathrm{O}$ & $\begin{array}{l}\text { Lactobacillus Rhamnosus in prevention of } \\
\text { chemotherapy-related diarrhea }\end{array}$ & DS: probiotic LGG & CRC & - \\
\hline NCT02770326 & $\mathrm{O}$ & $\begin{array}{l}\text { Safety of stool transplant for patients with } \\
\text { difficult to treat } C \text {. difficile infection }\end{array}$ & FMT & $\begin{array}{l}\text { Various } \\
\text { Cancers }\end{array}$ & - \\
\hline NCT02928523 & $\mathrm{C}$ & $\begin{array}{l}\text { Prevention of dysbiosis complications with } \\
\text { autologous FMT in acute myeloid leukemia } \\
\text { patients undergoing intensive treatment } \\
\text { (ODYSSEE) }\end{array}$ & Autologous FMT & AML & - \\
\hline NCT03353402 & $\mathrm{O}$ & $\begin{array}{l}\text { FMT in metastatic melanoma patients who } \\
\text { failed immunotherapy }\end{array}$ & FMT & Melanoma & - \\
\hline NCT03341143 & $\mathrm{O}$ & FMT in melanoma patients & $\begin{array}{l}\text { FMT with } \\
\text { Pembrolizumab }\end{array}$ & Melanoma & - \\
\hline
\end{tabular}

* Registered at ClinicalTrials.gov; Abbreviations: C, Closed; O, Ongoing; GI, Gastrointestinal; DS, Dietary Supplement; CRC, Colorectal Cancer; CC, Colon Cancer; RC, Rectal Cancer; BC, Breast Cancer; NSCLC, Non-Small Cell Lung Cancer; PC, Periampullary Carcinoma; LC, Lung Cancer; HCC, Hepatocellular Carcinoma; AML, Acute Myeloid Leukemia.

Given the beneficial role of LGG in ameliorating the anti-cancer therapy-related side effects, many groups are investigating also the potential role that LGG might have in the direct modulation of cancer development. In particular, it has been observed that LGG exerts its effect either directly on cancer cells or indirectly through the modulation of the immune system, both in vitro and in vivo.

Firstly, LGG is capable of counteracting cancer growth. It has been demonstrated within several in vitro tumor models (including colorectal, ovary, breast, cervical, hepatic and oral squamous) that LGG is able to exert either anti-proliferative effects or anti-metastatic effects [102-106]. This could be mediated through the direct modulation of several host's proliferation pathways, such as mTOR or WNT [107]. In addition, LGG prevents polyps' formation in a colorectal APC/min mouse cancer model, and reduces colitis-associated cancer in mice [108,109].

Secondly, LGG can influence host's immune system, therefore helping the host to eliminate newly developing cancer cells. In fact, treatment with LGG in a rat dimethyl hydrazine-induced colon cancer model, is able to reduce the tumor mass through the modulation of the commensal gut microbiome and the downregulation of pro-inflammatory molecules produced by both gastrointestinal cells and gut-resident immune cells [110]. Additionally, host's DC exposed to LGG induce TH1 immune cells polarization and, in turn, antitumor immune-response potentiation [111]. 
LGG triggers the immune response also within the normal not transformed gut epithelium, thus protecting towards inflammation, which can support the formation of a cancer-favorable milieu [112]. On this line, it has been recently observed how LGG attenuates NLRP6-mediated inflammasomes activation in the intestine [113]. LGG administration can also change gene expression in intestinal porcine epithelial cells and intestine myo-fibroblasts towards an anti-inflammatory profile $[114,115]$. A complete list of the latest in vitro and in vivo studies untangling the complex role of LGG in cancer development is reported in Table 2.

Table 2. The last three-years in vitro and in vivo studies describing the role of LGG in cancer.

\begin{tabular}{lccc}
\hline \multicolumn{1}{c}{ LGG-Mediated Effect } & Experimental Model & Target Cells & Reference \\
\hline $\begin{array}{l}\text { Anti-inflammatory and anti-cancer effect in colon DMH } \\
\text { cancer model }\end{array}$ & rats & cancer cells & [110] \\
\hline $\begin{array}{l}\text { Dendritic cells exposed to LGG induce TH1 polarization and } \\
\text { antitumor response potentiation }\end{array}$ & ex-vivo immune cells & $\begin{array}{c}\text { cancer and } \\
\text { immune cells }\end{array}$ & [111] \\
\hline Anti-proliferative effects on colon adenocarcinoma cells & cell culture & cancer cells & {$[102]$} \\
\hline Anti-metastatic effects on malignant cells & cell culture & cancer cells & {$[103]$} \\
\hline $\begin{array}{l}\text { Promotion of IgA production through upregulation of APRIL } \\
\text { expression in intestinal epithelial cells }\end{array}$ & cell culture and mice & $\begin{array}{c}\text { cancer and } \\
\text { normal cells }\end{array}$ & [89] \\
\hline Change in transcriptome of small intestine cells & mice & normal cells & {$[112]$} \\
\hline $\begin{array}{l}\text { Attenuation of the NLRP6-mediated inflammasomes in the } \\
\text { intestine }\end{array}$ & pigs & normal cells & {$[113]$} \\
\hline $\begin{array}{l}\text { Prevention of polyp formation in colorectal APC/min cancer } \\
\text { model }\end{array}$ & mice & cancer cells & {$[108]$} \\
\hline $\begin{array}{l}\text { Modulation of mTOR and Wnt/ } \beta \text {-catenin pathways genes in } \\
\text { cancer cell lines (colon, cervical, breast) }\end{array}$ & cell culture & cancer cells & {$[107]$} \\
\hline Anti-oxidative effects on CC cells & cell culture & cancer cells & {$[104]$} \\
\hline Inhibition of growth of hepatic cancer cells & cell culture & cancer cells & {$[105]$} \\
\hline Anti-cancer effect on oral squamous cell carcinoma & cell culture & cancer cells & {$[106]$} \\
\hline Reduction of colitis associated cancer & mice & cancer cells & {$[109]$} \\
\hline $\begin{array}{l}\text { Change of gene expression towards anti-inflammatory profile } \\
\text { in intestinal porcine epithelial cells }\end{array}$ & cell culture & normal cells & {$[114]$} \\
\hline $\begin{array}{l}\text { Anti-inflammatory effects in myo-fibroblast colonic cells but } \\
\text { not in cancer cells }\end{array}$ & cell culture and mice & normal cells & {$[115]$} \\
\hline Attenuation of 5-FU-mediated intestinal injury & mice & normal cells & {$[91]$} \\
\hline Protection of gut epithelial cells from radiation injury & mice & normal cells & {$[92]$} \\
\hline $\begin{array}{l}\text { Preservation of the gut microbiota balance and intestinal } \\
\text { epithelial barrier }\end{array}$ & pigs & normal cells & {$[93]$} \\
\hline
\end{tabular}

Altogether, the currently ongoing clinical studies (dissecting the beneficial effects of LGG administration during anti-cancer therapy), coupled with the in vitro and in vivo studies (supporting LGG as a direct cancer modulator), make LGG a suitable candidate to be further characterized as possible adjuvant in integrated anti-cancer therapies.

\section{Gut Microbiota and the Inflammasomes}

In addition to the role of gatekeeper with the GBA, the gut represents also the interface between the microbiome and the host's immune system. The gut microbial population plays a key role in training, functioning and stimulating the host immune system, with the final effect of developing tolerance towards beneficial microbiota and eliciting immune response against gut pathogens [76].

Within the Sections 2 and 3 of this review, how the gut microbiome is able to deeply influence the host's immune and inflammatory responses, with either protective or detrimental effects on the oncogenesis, depending on the nature of the bacteria and the host's immune cells involved, has been described. Additionally, gut microbiome interacts both with immune cells and gut cells through the activation of the so-called inflammasomes. Inflammasomes are multiprotein intracellular complexes 
expressed by both immune cells and epithelial cells. They can detect pathogenic and non-pathogenic microorganisms-derived molecules, as well as sterile stressors molecules, via a subset of cytoplasmic pattern recognition receptors (PRRs), called NOD-like Receptors (NLRs) [116].

Given the ability of such multiprotein complexes to sense both microbial and endogenous stimuli, inflammasomes are regarded as the guardians of cellular and tissue integrity. Upon disruption of host's homeostasis and activation of inflammasomes sensors, a strong inflammatory response is activated. In detail, the inflammasomes complex mediates the activation of caspase- 1 which, in turn, triggers the secretion of the proinflammatory cytokines interleukin-1 $\beta$ (IL-1 $\beta$ ) and interleukin-18 (IL-18) as well as pyroptosis, a form of programmed cell death [117]. Dysregulation of inflammasomes results in a variety of diseases, ranging from autoimmunity to cancer [118]. Importantly, among all the stimuli, inflammasomes are also capable of sensing host-microbiota interactions, thus taking an active role in response to commensal and pathogenic bacteria [116].

The role of the inflammasomes in tumorigenesis is controversial. In fact, the inflammasomes have been shown to be either tumor-promoting or tumor-suppressive, depending on the nature of both the tumor and its microenvironment. The exact outcome of the inflammasomes activation depends on multiple factors, including its expression pattern and effector molecules, together with the tumor nature and stage. Importantly, the gut microbiome may also influence the outcome of the specific inflammasomes activation [119]. Currently, we have very limited knowledge on the mechanisms responsible for inflammasomes activation during tumor development. Multiple studies using different mice deficient for inflammasomes components (including NLRP3, NLRP1, NLRP6, NLRC4 and Caspase-1) found that the inflammasomes protect mice from colitis-associated CRC [120-124]. Importantly, the inflammasomes effector IL-18, but not IL-1 $\beta$, plays a pivotal role in suppressing colitis. In fact, IL-18 KO or IL-18R KO mice are also highly sensitive to colitis-associated CRC [124,125]. All these studies highlight the importance of inflammasomes-dependent IL-18 production in suppressing CRC. On the contrary, inflammasomes activation results detrimental to the development of lung, skin, breast and pancreatic cancer. In those cases, IL-1 $\beta$ is the key player, acting as pro-inflammatory, tumor-promoting trigger [126-130].

The commensal microbiota and their bioproducts are sensed by epithelial cells and innate immune cells via innate receptors, including the inflammasomal NLRs. In particular, inflammasomes-mediated IL-18 is critical for intestinal tissue remodeling and gastro-intestinal barrier maintenance. Commensal bacteria and their bioproducts induce inflammasomes activation and IL-18 production in the gut, which, in turn, prevents intestinal barrier disruption and dysbiosis [121,124,131-133]. Deficiency in inflammasomes components leads to reduced production of IL-18, resulting in an intestinal barrier impairment. Such damage causes larger commensal bacteria penetration, and increased inflammation, which may finally trigger tumorigenesis. Dysbiosis has been observed in mice deficient for inflammasomes components, including NLRP6, ASC, caspase-1, and IL-18 [131-134]. Importantly, it has been proposed that inflammasomal NLRP6 is required for the commensal bacteria homeostasis. NLRP6 KO mice show dysbiosis and increased incidence of inflammation-associated CRC [135-137]. Inflammasomes and IL-18 are protective in inflammation-induced CRC. Further studies are needed to assess whether inflammasomes and/or IL-18 inhibit CRC development in genetic CRC models (such as the APC/min mice), as well as in human CRC. Relevantly, Lactobacilli are able to activate the inflammasomes in human primary macrophages, as well as in primary mammalian gut epithelial cells, as defense mechanism against viral infection or epithelial injury [138].

Therefore, inflammasomes represent a double-edged sword in tumorigenesis and the gut microbiome may influence the outcome of the specific inflammasome activation during tumorigenesis. In CRC inflammasomes activation has a protective role, on the contrary in breast and skin cancers their triggering leads to detrimental outcomes [119]. Regarding the correlation between inflammasomes, microbiome and cancer, NRPL6 plays a key role in colorectal carcinogenesis and, in particular, NLRP6 regulates susceptibility to intestinal inflammation through its microbiome-modulatory activity [139]. 


\section{Gut Microbiota and Anti-Cancer Therapy}

Anti-cancer therapies are designed with the final goal of being effective in the eradication of the targeted malignancy. Because almost every available anti-cancer treatment is toxic also towards normal cells, their use may be coupled with side effects, some of which can compromise the overall survival of the patients [140].

Additionally, tumors are intrinsically complex: as they attempt to accumulate mutations, cancers evolve and adapt to the hosting organism [141]. In fact, cancers derive from the stochastic acquisition of driver mutations within genes involved in key processes, including DNA duplication, DNA repair, oxidative stress response. Such accumulation finally allows the transformation of a normal cell into a malignant one [141]. Both the initiation and the progression of a tumor may be viewed as a blended impairment of such fundamental cellular processes, meaning that from one original cancer cell might derive a molecularly varied bulk tumor made of multiple clones of cancer cells, each one displaying a differential intrinsic sensitivity to the anti-cancer therapies [142]. This heterogeneity derives from intrinsic tumor cellular genomic instability, ranging from microsatellite instability (due to impairments of the DNA mismatch repair system) to chromosomal instability (arising from segregation errors during cell mitosis) $[143,144]$. On top of that, such genetic mechanisms might be coupled with epigenetics, transcriptional and post-transcriptional intracellular changes, finally leading to a growing tumor complexity, through time and space [145].

Importantly, this intra-tumoral variety is tightly linked with the development of the resistance to therapy, considered the first cause of failure of the available anti-cancer treatments, as well as subsequent tumor relapses [146]. To fight such resistance, integrated therapies and personalized approaches, based on the specific genetic features of the malignancy, are in continuous progress [146].

Developing malignant cells not only are subjected to their intrinsic heterogeneity, additionally they are recognized and eliminated by the host's immune system [147]. On their side, tumor cells, thanks to their genetic instability, constantly evolve novel strategies to escape from such immunosurveillance and expand within the host [147]. Along with chemotherapy and radiotherapy, a novel anti-cancer approach is considered the so-called targeted immunotherapy, bearing the dual role of both boosting the host anti-tumor immune response, and, at the same time, helping to hit cancer resistance and recurrence mechanisms $[148,149]$.

Modulating gut microbiome may deeply influence the outcome of anti-cancer therapies. In fact, radiotherapy, chemotherapy and immunotherapy treatments can all modify patients' microbiome and, at the same time, microbiome composition can deeply affect patients' response to such therapies [150]. It is therefore fundamental to identify which are the factors able to influence the gut microbiome and, in turn, to find novel strategies to manipulate the gut microbiome, with the main goal of finally improving patients' therapeutic outcome. Specifically, interventions on microbiome may be pivotal to ameliorate anti-cancer therapy-related toxicity, as well as to improve anti-cancer therapy efficacy [151,152]. The emerging role of the gut microbiome in cancer therapy is summarized in Figure 3.

Back in 1890 two heat-inactivated microorganisms (Streptococci) were injected intratumorally for the very first time in humans as an attempt to cure cancer $[153,154]$. Furthermore, several decades later, Mycobacterium bovis was successfully injected into bladder in patients, following the resection of a bladder tumor. It has been observed that the bacteria, by inducing a local immune response, helped to reduce the relapse of the tumor [155]. Moreover, it has been discovered how oral administration of Lactobacillus casei decreased superficial bladder cancer recurrence [156]. The mechanism behind involves the direct bacterial stimulation of host's NK cells and macrophages, in turn responsible of a strong antitumoral immune response [157].

These observations paved the way for many published, as well as ongoing, clinical trials, based on the usage of gut bacterial attenuated strains in anti-cancer therapy. These trials are shedding light on the key role of such bacteria on triggering anti-tumor immune response [158]. For example, it has been observed that the intradermal injection of Mycobacterium obuense in melanoma and in pancreatic 
ductal carcinoma activates antitumoral immune response, acting on host's antigen presenting cells (APCs) and cytotoxic T cells $[159,160]$. Additional clinical trials further revealed how attenuated bacteria injected directly into the tumor mass are able to both stimulate anti-tumoral immune response and also have a direct cytotoxic effect on the tumor cells, because their capability of colonizing tumors, as observed in several different refractory solid tumor studies, towards the administration of attenuated and/or genetically modified Salmonella typhimurium [161-163]. Although these results are encouraging, many clinical trials are currently ongoing in order to ameliorate the patients' clinical outcomes, given bacteria-associated toxicity, mainly correlated to their long half-life [163].

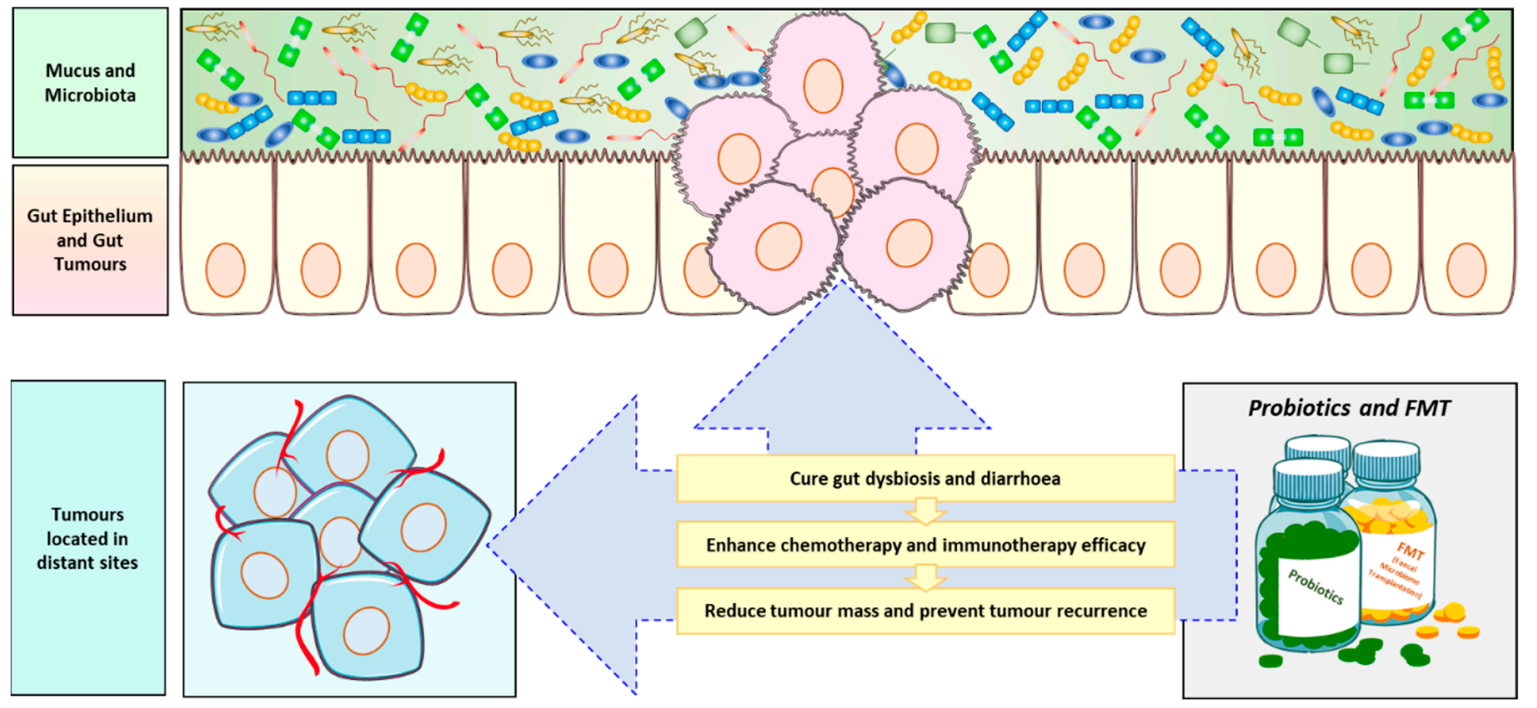

Figure 3. Role of probiotics in anti-cancer therapy. Probiotics and Fecal Microbiome Transplantation (FMT) are currently studied as anti-cancer adjuvants to fight dysbiosis following anti-cancer therapy, to increase chemotherapy and immunotherapy efficacy and to both reduce tumor mass and prevent tumor recurrence.

\subsection{Modulation of Gut Microbiota to Enhance Chemotherapy and Immunotherapy Efficacy}

The microbiota, when affected by dysbiosis, can deeply influence both cancer pathogenesis (as reported in Section 2) and its therapeutic outcome. In particular, the regulation of such therapeutic outcome is tightly connected with the ability of the gut microbiota to metabolize anti-tumoral compounds, as well as to modulate host's immune response and inflammation pathways [164]. These two effects combined together may explain the strong involvement of the patient's microbiome composition in affecting the efficacy of both chemotherapy and immunotherapy [19].

With regard to chemotherapy, it has been reported how tumor-bearing mice, either germ free or having their gut microbiota depleted after antibiotics therapy, do not respond to oxaliplatin drug treatment. The explanation is that commensal microbiome members within the gut of the mice might produce TLR agonists, thus promoting the rise of an oxidative stress milieu and tumor cell death. As a direct consequence, without a healthy gut microbiota there is a decreased microbiota-dependent ROS production, thus a less effective chemotherapeutic response [165]. Consistently, mice bearing lung tumors treated with cisplatin coupled with antibiotics, survive less and develop bigger tumors. If cisplatin is combined with probiotics, such as Lactobacilli, mice show an improved response to therapy. The mechanism involves the induction of pro-apoptotic genes within the tumor mass and the enhancement of host's immune response [166].

Another widely used anti-cancer molecule, cyclophosphamide, coupled with oral bacterial administration (Lactobacillus johonsoni and Enterococcus hirae), leads to the conversion of T cells from naïve to pro-inflammatory T helper 17 (TH17), with the final effect of improving cyclophosphamide efficacy in tumor-bearing mice $[167,168]$. 
With reference to immunotherapy, the administration of $\mathrm{CpG}$ oligodeoxynucleotides, synthetic molecules mimicking bacterial DNA, strongly stimulate the immune system, therefore showing anti-tumor activity in several cancers [169]. Along this line, the intra-tumoral injection of CpG oligodeoxynucleotides administered together with an anti-interleukin-10 receptor (IL-10R) antibody, induce TNF production from tumor infiltrating myeloid cells and, in turn, reduce the growth several types of tumors in mice [165]. Moreover, the administration of a specific bacteria, Alistipes shahii, to antibiotic-treated tumor bearing mice, restores TNF production with a notable improvement in the therapeutic outcome [165].

Given the multiplicity of effects that gut microbiome may play on the host's immune system, it is not surprising that emerging studies strongly linked the patients' microbiome composition with the intrinsic efficacy of immune checkpoint inhibitors-based immunotherapy, in the treatments of different solid tumors [170-172]. Immune checkpoint inhibition consists in the administration of therapeutic agents able to block the immune-inhibitory pathway, thus modulating $\mathrm{T}$ cell activation against tumor target cells. The currently marketed checkpoint inhibitors are in monoclonal antibodies targeting cytotoxic T lymphocyte-associated protein 4 (CTLA4) or the programmed death 1 (PD1) located on T cell surfaces, or its ligand, programmed death ligand 1 (PD-L1), expressed by the APCs [173]. While CTLA-4 regulates T cells proliferation early in the immune response within the lymph nodes, PD-1 suppresses T-cell activation later, within the body periphery [174].

A few years ago, two studies suggested the potential involvement of the gut microbiome in modulating the efficacy of such anti CTLA4 and anti-PD1 based therapies $[175,176]$. Vetizou et al. demonstrated that the efficacy of anti-CTLA4 antibodies in reducing sarcoma tumor growth in mice is significantly increased when the gut microbiome is enriched in Bacteroides fragilis and Burkholderia cepacia [175]. On the same line, Sivan et al., found that the efficacy of PD-L1 targeting-antibody in the cure of melanoma in mice is improved in the presence of gut microbiome enriched in Bifidobacterium species [176]. In fact, they demonstrated that oral administration of a cocktail of Bifidobacterium species combined with the anti-PD-L1 antibody, specifically boosts T cell response and blocks the melanoma growth [176].

Multiple translational studies, published in 2018, further support the pivotal role of the gut microbiome in modulating the response to immune checkpoint blockade [170-172]. In particular, Routy et al. [170] found that melanoma patients treated with antibiotics along with the anti-PD1/anti-PD-L1 immunotherapy had a lower survival rate. Importantly, metagenomics analysis of patients' fecal gut microbiome showed a difference in the composition of their gut microbiome. Anti-PD1 responders were enriched in two phyla (Akkermansia and Alistipes). Performing FMT from patients to germ free mice, the authors found that Akkermansia muciniphila (alone or in combination with Enterococcus hirae) was able to increase intra-tumoral cytotoxic $\mathrm{T}$ cell infiltrates, thus increasing the PD-1 blockade response in mice [170]. In parallel, Gopalakrishnan et al. [171] demonstrated through metagenomics analysis of melanoma patients' fecal samples that the anti-PD1 responders' microbiome was different in composition compared with that of non-responders. The authors observed in patient's gut microbiome an increase in the abundance of Clostridiales, Ruminococcaceae and Faecalibacteriae. Functional studies performed with FMT in germ free mice further demonstrated how treating mice with the identified bacteria, along with the anti-PD1 therapy, enhanced the anti-cancer effects and reduces the melanoma growth [171]. Along the same line, Matson et al. [172] performed a metagenomics characterization of stools samples from melanoma patients treated with immune checkpoint inhibitors, further corroborating the finding that responders showed a different microbiome compared to those not responding to therapy. They identified and functionally proven in vivo the importance of Bifidobacterium longum, Enterococcus faecium and Collinsella aerofaciens in ameliorating anti-PD-L1 efficacy [172].

Although the immune checkpoint inhibitors have success in treating various malignancies, there is still a significant number of patients that can use such therapy only for a limited amount of time, given the occurrence of strong toxic side effects, including gut inflammation, due to the 
subsequent immune-dysregulation (i.e., autoimmunity) [177]. In animals, oral gavage of Bacterioides fragilis and Burkholderia cepacia demonstrated an amelioration of such immunotherapy-associated toxic side effects [175]. In line with this observation, it has been seen that patients treated with anti-CTLA4 antibody, toxic side effects are mediated by an increased abundance of Firmicutes, such as Faecalisbacterium, and a decreased abundance of Bacterioides [178,179]. Altogether, these data provide a strong evidence of the role of gut microbiota composition in modulating the effect of both immunotherapy response and toxicity.

Even if the last decade witnessed massive advances in unveiling the role of gut microbiome in cancer and other diseases, there are still many obstacles for translating basic microbiome research into therapeutic applications. Among the gut bacteria can develop potential pathogens and that could limit, or at least slow down, the translation of the in vitro and in vivo results to the clinic. In light of the novel studies reported above, any antibacterial therapy altering the intestinal equilibrium, during anti-cancer therapy, needs to be carefully evaluated. In fact, the heterogenous patients' microbiome can either be detrimental or beneficial to tumor progression and therapy, depending on its composition and prevailing species. As further discussed below, looking at the effects of probiotics treatments in anti-cancer therapy, it might be necessary in the future to pursue a personalized approach, based on the specific patient's microbiome composition.

\subsection{Use of Probiotics in Oncology}

As discussed above, chemotherapy, targeted therapy, immunotherapy and radiotherapy represent the pillars of the currently available anti-cancer treatments. Such treatments may cause diverse and even drastic side effects in patients [180-186]. Several preclinical studies and clinical trials share the common goal of evaluating the overall efficacy of probiotics in decreasing the risk and the severity of such anti-cancer treatments related-toxicity, mainly diarrhea and mucositis $[187,188]$. In fact, the aim of administering probiotics to cancer patients, principally Lactobacilli, is to re-populate the compromised patients' gut microbiota, thus re-establishing the levels and functionality of the commensal bacteria, depleted after the treatments [189]. Although probiotics are generally regarded as safe, the main concerns of administering them to immunocompromised cancer patients are both the potential risk of opportunistic infection development and the transfer of antibiotics resistance [190,191]. Despite of that, probiotics administration in multiple trials has shown beneficial effects on ameliorating diarrhea and other gut-related damages following anti-cancer therapy, thus re-establishing a healthy intestinal microbiota composition [192]. Moreover, within the Multinational Association of Supportive Care in Cancer and International Society of Oral Oncology (MASCC/ISOO) and European Society of Medical Oncology (ESMO) Clinical Practice Guidelines for Gastrointestinal Mucositis, probiotics containing Lactobacillus species are suggested be used to prevent diarrhea in patients receiving chemotherapy and / or radiation therapy for a pelvic malignancy (Level of evidence III) [193,194].

Given that a growing body of studies corroborated the fundamental role of microbiome in cancer, many clinical studies are currently ongoing with the common aim of investigating the therapeutic potential of manipulating gut microbiota in cancer patients. Results from early clinical trials are promising. In 2010, it was assessed for the first time the interaction between probiotic administration, variation of gut microbiota composition, and regulation of intestinal immune-functions in cancer patients undergoing colorectal resection [95]. A mixture of two probiotic species Bifidobacterium longum (BB536) and Lactobacillus johnsonii (La1) was administered to the patients in the double-blind study, finding that one of that, La1, was able to adhere to the colonic mucosa, thereby reducing the concentration of gut pathogens and modulating the local immunity [95]. Subsequently, in 2014, a randomized double-blind controlled trial assessed the beneficial administration of the probiotics Bifilact (Lactobacillus acidophilus LAC361 and Bifidobacterium longum BB536) on significantly reducing moderate and severe treatment-induced diarrhea during pelvic radiation [96]. On the same line, in 2015, for the first time, a clinical trial evaluated the probiotic formula Colon Dophilus (mixture of 10 different probiotic strains) in the prevention of diarrhea in patients with metastatic CRC, treated with 
irinotecan-based chemotherapy, suggesting that the administration of such probiotics is safe and leads to a reduction in the incidence and severity of diarrhea and chemotherapy induced gastrointestinal toxicity [97]. In 2016, another double-blind, randomized trial demonstrated that the administration of a combination of prebiotics and probiotics to patients subjected to CRC resection may alleviate irritable bowel syndrome (IBS), often following the operation [98]. In the same year, another trial further analyzed the effects of randomized oral administration of the probiotic Saccaromices bulardii in CRC patients. The authors found that this probiotic was able to downregulate pro-inflammatory cytokines in treated patients, although with lacking effects on the post-operative infection rates [99]. Moreover, according to the result of a trial published in 2017, the randomized administration of Bifidobacterium lactis and Lactobacillus acidophilus to CRC patients, can change the epigenetic patterns of tumor tissue from its baseline, with potential therapeutic benefits in CRC by manipulation of the gut microbiota [100]. The same year a randomized clinical trial with CRC patients demonstrated that the perioperative administration of a mixture of prebiotics and probiotics, significantly reduced postoperative infection rates in patients with CRC [101].

Regardless the observed beneficial effects, larger and controlled clinical trials are further needed to truly endorse both the efficacy and the safety of administering selected species of probiotics during or following anti-cancer treatments (Table 1).

\subsection{Use of Fecal Microbiota Transplantation (FMT) in Oncology}

The exchange of gut microbiota between individuals has been used to cure pathogens infections or in the treatment of gut inflammatory disease and dysbiosis. For example, FMT has been used to cure recurrent Clostridium difficile duodenal infection $[195,196]$. Moreover, FMT has been used in a Graft Versus Host Disease (GVHD) after allogeneic stem cell transplantation [197]. Regarding anti-tumor therapeutic applications, preclinical studies performed in mice demonstrated the efficacy of FMT in reducing colon tumorigenesis, although the efficacy in clinical trials still needs to be further proven [198]. Several clinical trials, designed to evaluate the use of FMT in cancer patients are currently ongoing, with the common goal of preventing and/or ameliorating intestinal side-effects of anti-cancer therapies in cancer patients (Table 1).

Despite the success of FMT, there is still a lack of control in this procedure because the whole gut microbiota is transferred along with the therapeutic bacteria species. Therefore, it is of key importance the careful control of the donors' health and their gut microbiome specific composition [199].

\section{Conclusions and Future Perspectives}

The relationship between gut resident microbiota and their host is complex. Each individual inherited a specific gut microbiota footprint since their birth, and their intestinal microbiota develops and changes with aging, diet and lifetime exposure to the heterogeneous environment. Indeed, this balance is very delicate and subjected to multiple changes during the entire lifespan.

Nowadays, there is a growing attention towards the characterization of the gastro-intestinal microbiota composition and functionalities. Genetics, together with functional studies, highlighted a dual role played by the gut microbiome in cancer. Some bacterial subpopulations are able to rise during gut dysbiosis and, in turn, to trigger the formation of an inflammatory and pro-cancerogenic environment. On the other hand, many gut derived probiotics are able to protect the host, re-establishing the conditions of a healthy intestinal microbiota within dysbiotic patients, including cancer patients.

LGG is a very good example of a probiotic well studied in cancer, often administered as complementary therapeutic to cure dysbiosis. Given the observed functions as anti-inflammatory and anti-cancer agent in both cellular and animal models, this probiotic may be suggested to be further characterized as adjuvant in integrated anti-cancer therapies in the future.

In line with that observation, this year have witnessed novel breakthrough studies on the association between probiotics and anti-cancer therapy efficacy, as three parallel studies identified 
specific gut species populating the gastro-intestinal tract of cancer immunotherapy responders, able to improve the efficacy of immunotherapy treatments.

That questions the usage of both probiotics and FMT in cancer therapy, either as tools to repopulate cancer patients' damaged intestine or even as proper adjuvants in immunotherapy and other kinds of anti-cancer therapies. Correspondingly, care needs to be pursued as patients are often immunocompromised, therefore it is important to evaluate the specific side effects of administering selected bacterial species to such sensitive individuals. In the future, the design of novel experimental trials may undertake a personalized-integrated approach, considering the specific clinical and pathological background of each single patient to be treated, in order to gain only the positive outcomes of probiotics administration and/or fecal transplants, possibly without any harmful side effect.

Author Contributions: Conceptualization: M.L., S.V.; Writing-Original Draft Preparation: S.V.; Figures and Tables: S.V.; Writing—Review \& Editing: S.V., R.S., S.C., L.F., M.S., S.S., F.T., G.L.B, G.T., M.L. All authors have approved the final version of the manuscript.

Funding: S.V. has been funded by a fellowship from the Italian League Against Cancer (LILT), Catania.

Acknowledgments: S.V. thanks the Italian League Against Cancer (LILT), Catania for its support.

Conflicts of Interest: M.L. is the PI of a research grant founded by Dicofarm Spa to his University Department. The other authors declare that the research was conducted in the absence of any commercial or financial relationships that could be construed as a potential conflict of interest.

\section{References}

1. Fitzmaurice, C.; Allen, C.; Barber, R.M.; Barregard, L.; Bhutta, Z.A.; Brenner, H.; Dicker, D.J.; Chimed-Orchir, O.; Dandona, R.; Dandona, L.; et al. Global, Regional, and National Cancer Incidence, Mortality, Years of Life Lost, Years Lived with Disability, and Disability-Adjusted Life-years for 32 Cancer Groups, 1990 to 2015: A Systematic Analysis for the Global Burden of Disease Study. JAMA Oncol. 2017, 3, 524-548. [CrossRef] [PubMed]

2. Collaborators, G.M.a.C.o.D. Global, regional, and national life expectancy, all-cause mortality, and cause-specific mortality for 249 causes of death, 1980-2015: A systematic analysis for the Global Burden of Disease Study 2015. Lancet 2016, 388, 1459-1544. [CrossRef]

3. Tomasetti, C.; Vogelstein, B. Cancer etiology. Variation in cancer risk among tissues can be explained by the number of stem cell divisions. Science 2015, 347, 78-81. [CrossRef] [PubMed]

4. Ashford, N.A.; Bauman, P.; Brown, H.S.; Clapp, R.W.; Finkel, A.M.; Gee, D.; Hattis, D.B.; Martuzzi, M.; Sasco, A.J.; Sass, J.B. Cancer risk: Role of environment. Science 2015, 347, 727. [CrossRef] [PubMed]

5. Anand, P.; Kunnumakkara, A.B.; Kunnumakara, A.B.; Sundaram, C.; Harikumar, K.B.; Tharakan, S.T.; Lai, O.S.; Sung, B.; Aggarwal, B.B. Cancer is a preventable disease that requires major lifestyle changes. Pharm. Res. 2008, 25, 2097-2116. [CrossRef] [PubMed]

6. Zhang, Y.J.; Li, S.; Gan, R.Y.; Zhou, T.; Xu, D.P.; Li, H.B. Impacts of gut bacteria on human health and diseases. Int. J. Mol. Sci. 2015, 16, 7493-7519. [CrossRef] [PubMed]

7. Feng, Q.; Chen, W.D.; Wang, Y.D. Gut Microbiota: An Integral Moderator in Health and Disease. Front. Microbiol. 2018, 9, 151. [CrossRef]

8. Lynch, S.V.; Pedersen, O. The Human Intestinal Microbiome in Health and Disease. N. Engl. J. Med. 2016, 375, 2369-2379. [CrossRef]

9. Greenhalgh, K.; Meyer, K.M.; Aagaard, K.M.; Wilmes, P. The human gut microbiome in health: Establishment and resilience of microbiota over a lifetime. Environ. Microbiol. 2016, 18, 2103-2116. [CrossRef]

10. Vaishnava, S.; Behrendt, C.L.; Ismail, A.S.; Eckmann, L.; Hooper, L.V. Paneth cells directly sense gut commensals and maintain homeostasis at the intestinal host-microbial interface. Proc. Natl. Acad. Sci. USA 2008, 105, 20858-20863. [CrossRef]

11. Belkaid, Y.; Naik, S. Compartmentalized and systemic control of tissue immunity by commensals. Nat. Immunol. 2013, 14, 646-653. [CrossRef] [PubMed]

12. Magnúsdóttir, S.; Ravcheev, D.; de Crécy-Lagard, V.; Thiele, I. Systematic genome assessment of B-vitamin biosynthesis suggests co-operation among gut microbes. Front. Genet. 2015, 6, 148. [CrossRef] [PubMed] 
13. Carding, S.; Verbeke, K.; Vipond, D.T.; Corfe, B.M.; Owen, L.J. Dysbiosis of the gut microbiota in disease. Microb. Ecol. Health Dis. 2015, 26, 26191. [CrossRef] [PubMed]

14. Grice, E.A.; Segre, J.A. The human microbiome: Our second genome. Annu. Rev. Genom. Hum. Genet. 2012, 13, 151-170. [CrossRef] [PubMed]

15. Geva-Zatorsky, N.; Sefik, E.; Kua, L.; Pasman, L.; Tan, T.G.; Ortiz-Lopez, A.; Yanortsang, T.B.; Yang, L.; Jupp, R.; Mathis, D.; et al. Mining the Human Gut Microbiota for Immunomodulatory Organisms. Cell 2017, 168, 928-943. [CrossRef] [PubMed]

16. Haber, A.L.; Biton, M.; Rogel, N.; Herbst, R.H.; Shekhar, K.; Smillie, C.; Burgin, G.; Delorey, T.M.; Howitt, M.R.; Katz, Y.; et al. A single-cell survey of the small intestinal epithelium. Nature 2017, 551, 333-339. [CrossRef]

17. Rothschild, D.; Weissbrod, O.; Barkan, E.; Kurilshikov, A.; Korem, T.; Zeevi, D.; Costea, P.I.; Godneva, A.; Kalka, I.N.; Bar, N.; et al. Environment dominates over host genetics in shaping human gut microbiota. Nature 2018, 555, 210-215. [CrossRef]

18. Korem, T.; Zeevi, D.; Suez, J.; Weinberger, A.; Avnit-Sagi, T.; Pompan-Lotan, M.; Matot, E.; Jona, G.; Harmelin, A.; Cohen, N.; et al. Growth dynamics of gut microbiota in health and disease inferred from single metagenomic samples. Science 2015, 349, 1101-1106. [CrossRef]

19. Gopalakrishnan, V.; Helmink, B.A.; Spencer, C.N.; Reuben, A.; Wargo, J.A. The Influence of the Gut Microbiome on Cancer, Immunity, and Cancer Immunotherapy. Cancer Cell 2018, 33, 570-580. [CrossRef]

20. Goodman, B.; Gardner, H. The microbiome and cancer. J. Pathol. 2018, 244, 667-676. [CrossRef]

21. Knight, R.; Callewaert, C.; Marotz, C.; Hyde, E.R.; Debelius, J.W.; McDonald, D.; Sogin, M.L. The Microbiome and Human Biology. Annu. Rev. Genom. Hum. Genet. 2017, 18, 65-86. [CrossRef] [PubMed]

22. Fulbright, L.E.; Ellermann, M.; Arthur, J.C. The microbiome and the hallmarks of cancer. PLoS Pathog. 2017, 13, e1006480. [CrossRef] [PubMed]

23. Gagnaire, A.; Nadel, B.; Raoult, D.; Neefjes, J.; Gorvel, J.P. Collateral damage: Insights into bacterial mechanisms that predispose host cells to cancer. Nat. Rev. Microbiol. 2017, 15, 109-128. [CrossRef] [PubMed]

24. Zitvogel, L.; Daillère, R.; Roberti, M.P.; Routy, B.; Kroemer, G. Anticancer effects of the microbiome and its products. Nat. Rev. Microbiol. 2017, 15, 465-478. [CrossRef]

25. Carabotti, M.; Scirocco, A.; Maselli, M.A.; Severi, C. The gut-brain axis: Interactions between enteric microbiota, central and enteric nervous systems. Ann. Gastroenterol. 2015, 28, 203-209. [PubMed]

26. Neuman, H.; Debelius, J.W.; Knight, R.; Koren, O. Microbial endocrinology: The interplay between the microbiota and the endocrine system. FEMS Microbiol. Rev. 2015, 39, 509-521. [CrossRef] [PubMed]

27. Sandrini, S.; Aldriwesh, M.; Alruways, M.; Freestone, P. Microbial endocrinology: Host-bacteria communication within the gut microbiome. J. Endocrinol. 2015, 225, R21-R34. [CrossRef] [PubMed]

28. Ceranowicz, P.; Warzecha, Z.; Dembinski, A. Peptidyl hormones of endocrine cells origin in the gut-Their discovery and physiological relevance. J. Physiol. Pharmacol. 2015, 66, 11-27.

29. Ravussin, Y.; Koren, O.; Spor, A.; LeDuc, C.; Gutman, R.; Stombaugh, J.; Knight, R.; Ley, R.E.; Leibel, R.L. Responses of gut microbiota to diet composition and weight loss in lean and obese mice. Obesity 2012, 20, 738-747. [CrossRef]

30. Queipo-Ortuño, M.I.; Seoane, L.M.; Murri, M.; Pardo, M.; Gomez-Zumaquero, J.M.; Cardona, F.; Casanueva, F.; Tinahones, F.J. Gut microbiota composition in male rat models under different nutritional status and physical activity and its association with serum leptin and ghrelin levels. PLoS ONE 2013, 8, e65465. [CrossRef]

31. Gensollen, T.; Iyer, S.S.; Kasper, D.L.; Blumberg, R.S. How colonization by microbiota in early life shapes the immune system. Science 2016, 352, 539-544. [CrossRef] [PubMed]

32. Schmidt, T.S.B.; Raes, J.; Bork, P. The Human Gut Microbiome: From Association to Modulation. Cell 2018, 172, 1198-1215. [CrossRef] [PubMed]

33. Bultman, S.J. Emerging roles of the microbiome in cancer. Carcinogenesis 2014, 35, 249-255. [CrossRef] [PubMed]

34. Cani, P.D. Human gut microbiome: Hopes, threats and promises. Gut 2018, 67, 1716-1725. [CrossRef] [PubMed]

35. Mohajeri, M.H.; Brummer, R.J.M.; Rastall, R.A.; Weersma, R.K.; Harmsen, H.J.M.; Faas, M.; Eggersdorfer, M. The role of the microbiome for human health: From basic science to clinical applications. Eur. J. Nutr. 2018, 57, 1-14. [CrossRef] [PubMed] 
36. Fukui, H.; Xu, X.; Miwa, H. Role of Gut Microbiota-Gut Hormone Axis in the Pathophysiology of Functional Gastrointestinal Disorders. J. Neurogastroenterol. Motil. 2018, 24, 367-386. [CrossRef]

37. Clarke, G.; Stilling, R.M.; Kennedy, P.J.; Stanton, C.; Cryan, J.F.; Dinan, T.G. Minireview: Gut microbiota: The neglected endocrine organ. Mol. Endocrinol. 2014, 28, 1221-1238. [CrossRef]

38. Jan, G.; Belzacq, A.S.; Haouzi, D.; Rouault, A.; Métivier, D.; Kroemer, G.; Brenner, C. Propionibacteria induce apoptosis of colorectal carcinoma cells via short-chain fatty acids acting on mitochondria. Cell Death Differ. 2002, 9, 179-188. [CrossRef]

39. Wei, W.; Sun, W.; Yu, S.; Yang, Y.; Ai, L. Butyrate production from high-fiber diet protects against lymphoma tumor. Leuk. Lymphoma 2016, 57, 2401-2408. [CrossRef]

40. Paulos, C.M.; Wrzesinski, C.; Kaiser, A.; Hinrichs, C.S.; Chieppa, M.; Cassard, L.; Palmer, D.C.; Boni, A.; Muranski, P.; Yu, Z.; et al. Microbial translocation augments the function of adoptively transferred self/tumor-specific CD8+ T cells via TLR4 signaling. J. Clin. Investig. 2007, 117, 2197-2204. [CrossRef]

41. Paavonen, J.; Naud, P.; Salmerón, J.; Wheeler, C.M.; Chow, S.N.; Apter, D.; Kitchener, H.; Castellsague, X.; Teixeira, J.C.; Skinner, S.R.; et al. Efficacy of human papillomavirus (HPV)-16/18 AS04-adjuvanted vaccine against cervical infection and precancer caused by oncogenic HPV types (PATRICIA): Final analysis of a double-blind, randomised study in young women. Lancet 2009, 374, 301-314. [CrossRef]

42. Aranda, F.; Bloy, N.; Pesquet, J.; Petit, B.; Chaba, K.; Sauvat, A.; Kepp, O.; Khadra, N.; Enot, D.; Pfirschke, C.; et al. Immune-dependent antineoplastic effects of cisplatin plus pyridoxine in non-small-cell lung cancer. Oncogene 2015, 34, 3053-3062. [CrossRef] [PubMed]

43. Dembiński, A.; Warzecha, Z.; Ceranowicz, P.; Dembiński, M.; Cieszkowski, J.; Gosiewski, T.; Bulanda, M.; Kuśnierz-Cabala, B.; Gałązka, K.; Konturek, P.C. Synergic Interaction of Rifaximin and Mutaflor (Escherichia coli Nissle 1917) in the Treatment of Acetic Acid-Induced Colitis in Rats. Gastroenterol. Res. Pract. 2016, 2016, 3126280. [CrossRef] [PubMed]

44. Konishi, H.; Fujiya, M.; Tanaka, H.; Ueno, N.; Moriichi, K.; Sasajima, J.; Ikuta, K.; Akutsu, H.; Tanabe, H.; Kohgo, Y. Probiotic-derived ferrichrome inhibits colon cancer progression via JNK-mediated apoptosis. Nat. Commun. 2016, 7, 12365. [CrossRef] [PubMed]

45. Lenoir, M.; Del Carmen, S.; Cortes-Perez, N.G.; Lozano-Ojalvo, D.; Muñoz-Provencio, D.; Chain, F.; Langella, P.; de Moreno de LeBlanc, A.; LeBlanc, J.G.; Bermúdez-Humarán, L.G. Lactobacillus casei BL23 regulates Treg and Th17 T-cell populations and reduces DMH-associated colorectal cancer. J. Gastroenterol. 2016, 51, 862-873. [CrossRef] [PubMed]

46. Lee, J.W.; Shin, J.G.; Kim, E.H.; Kang, H.E.; Yim, I.B.; Kim, J.Y.; Joo, H.G.; Woo, H.J. Immunomodulatory and antitumor effects in vivo by the cytoplasmic fraction of Lactobacillus casei and Bifidobacterium longum. J. Vet. Sci. 2004, 5, 41-48. [PubMed]

47. Baldwin, C.; Millette, M.; Oth, D.; Ruiz, M.T.; Luquet, F.M.; Lacroix, M. Probiotic Lactobacillus acidophilus and L. casei mix sensitize colorectal tumoral cells to 5-fluorouracil-induced apoptosis. Nutr. Cancer 2010, 62, 371-378. [CrossRef] [PubMed]

48. Takagi, A.; Ikemura, H.; Matsuzaki, T.; Sato, M.; Nomoto, K.; Morotomi, M.; Yokokura, T. Relationship between the in vitro response of dendritic cells to Lactobacillus and prevention of tumorigenesis in the mouse. J. Gastroenterol. 2008, 43, 661-669. [CrossRef] [PubMed]

49. Lane, E.R.; Zisman, T.L.; Suskind, D.L. The microbiota in inflammatory bowel disease: Current and therapeutic insights. J. Inflamm. Res. 2017, 10, 63-73. [CrossRef]

50. Caputi, V.; Giron, M.C. Microbiome-Gut-Brain Axis and Toll-Like Receptors in Parkinson's Disease. Int. J. Mol. Sci. 2018, 19, 1689. [CrossRef]

51. Rea, D.; Coppola, G.; Palma, G.; Barbieri, A.; Luciano, A.; Del Prete, P.; Rossetti, S.; Berretta, M.; Facchini, G.; Perdonà, S.; et al. Microbiota effects on cancer: From risks to therapies. Oncotarget 2018, 9, 17915-17927. [CrossRef] [PubMed]

52. Sheflin, A.M.; Whitney, A.K.; Weir, T.L. Cancer-promoting effects of microbial dysbiosis. Curr. Oncol. Rep. 2014, 16, 406. [CrossRef] [PubMed]

53. Bhatt, A.P.; Redinbo, M.R.; Bultman, S.J. The role of the microbiome in cancer development and therapy. CA Cancer J. Clin. 2017, 67, 326-344. [CrossRef] [PubMed]

54. Arthur, J.C.; Perez-Chanona, E.; Mühlbauer, M.; Tomkovich, S.; Uronis, J.M.; Fan, T.J.; Campbell, B.J.; Abujamel, T.; Dogan, B.; Rogers, A.B.; et al. Intestinal inflammation targets cancer-inducing activity of the microbiota. Science 2012, 338, 120-123. [CrossRef] [PubMed] 
55. Nougayrède, J.P.; Homburg, S.; Taieb, F.; Boury, M.; Brzuszkiewicz, E.; Gottschalk, G.; Buchrieser, C.; Hacker, J.; Dobrindt, U.; Oswald, E. Escherichia coli induces DNA double-strand breaks in eukaryotic cells. Science 2006, 313, 848-851. [CrossRef] [PubMed]

56. Hatakeyama, M. Structure and function of Helicobacter pylori CagA, the first-identified bacterial protein involved in human cancer. Proc. Jpn. Acad. Ser. B Phys. Biol. Sci. 2017, 93, 196-219. [CrossRef] [PubMed]

57. Moss, S.F. The Clinical Evidence Linking. Cell. Mol. Gastroenterol. Hepatol. 2017, 3, 183-191. [CrossRef] [PubMed]

58. Kim, J.J.; Tao, H.; Carloni, E.; Leung, W.K.; Graham, D.Y.; Sepulveda, A.R. Helicobacter pylori impairs DNA mismatch repair in gastric epithelial cells. Gastroenterology 2002, 123, 542-553. [CrossRef]

59. Toller, I.M.; Neelsen, K.J.; Steger, M.; Hartung, M.L.; Hottiger, M.O.; Stucki, M.; Kalali, B.; Gerhard, M.; Sartori, A.A.; Lopes, M.; et al. Carcinogenic bacterial pathogen Helicobacter pylori triggers DNA double-strand breaks and a DNA damage response in its host cells. Proc. Natl. Acad. Sci. USA 2011, 108, 14944-14949. [CrossRef]

60. Grasso, F.; Frisan, T. Bacterial Genotoxins: Merging the DNA Damage Response into Infection Biology. Biomolecules 2015, 5, 1762-1782. [CrossRef]

61. Halazonetis, T.D. Constitutively active DNA damage checkpoint pathways as the driving force for the high frequency of p53 mutations in human cancer. DNA Repair 2004, 3, 1057-1062. [CrossRef]

62. Yao, Y.; Dai, W. Genomic Instability and Cancer. J. Carcinog. Mutagen. 2014, 5. [CrossRef]

63. Frisan, T. Bacterial genotoxins: The long journey to the nucleus of mammalian cells. Biochim. Biophys. Acta 2016, 1858, 567-575. [CrossRef] [PubMed]

64. Lara-Tejero, M.; Galán, J.E. A bacterial toxin that controls cell cycle progression as a deoxyribonuclease I-like protein. Science 2000, 290, 354-357. [CrossRef]

65. Bergounioux, J.; Elisee, R.; Prunier, A.L.; Donnadieu, F.; Sperandio, B.; Sansonetti, P.; Arbibe, L. Calpain activation by the Shigella flexneri effector VirA regulates key steps in the formation and life of the bacterium's epithelial niche. Cell Host Microbe 2012, 11, 240-252. [CrossRef] [PubMed]

66. Buti, L.; Spooner, E.; Van der Veen, A.G.; Rappuoli, R.; Covacci, A.; Ploegh, H.L. Helicobacter pylori cytotoxin-associated gene A (CagA) subverts the apoptosis-stimulating protein of p53 (ASPP2) tumor suppressor pathway of the host. Proc. Natl. Acad. Sci. USA 2011, 108, 9238-9243. [CrossRef]

67. Murata-Kamiya, N.; Kurashima, Y.; Teishikata, Y.; Yamahashi, Y.; Saito, Y.; Higashi, H.; Aburatani, H.; Akiyama, T.; Peek, R.M.; Azuma, T.; et al. Helicobacter pylori CagA interacts with E-cadherin and deregulates the beta-catenin signal that promotes intestinal transdifferentiation in gastric epithelial cells. Oncogene 2007, 26, 4617-4626. [CrossRef]

68. Rubinstein, M.R.; Wang, X.; Liu, W.; Hao, Y.; Cai, G.; Han, Y.W. Fusobacterium nucleatum promotes colorectal carcinogenesis by modulating E-cadherin/ $\beta$-catenin signaling via its FadA adhesin. Cell Host Microbe 2013, 14, 195-206. [CrossRef]

69. Wu, S.; Rhee, K.J.; Zhang, M.; Franco, A.; Sears, C.L. Bacteroides fragilis toxin stimulates intestinal epithelial cell shedding and gamma-secretase-dependent E-cadherin cleavage. J. Cell Sci. 2007, 120, 1944-1952. [CrossRef]

70. Lu, R.; Wu, S.; Zhang, Y.G.; Xia, Y.; Liu, X.; Zheng, Y.; Chen, H.; Schaefer, K.L.; Zhou, Z.; Bissonnette, M.; et al. Enteric bacterial protein AvrA promotes colonic tumorigenesis and activates colonic beta-catenin signaling pathway. Oncogenesis 2014, 3, e105. [CrossRef]

71. Bronte-Tinkew, D.M.; Terebiznik, M.; Franco, A.; Ang, M.; Ahn, D.; Mimuro, H.; Sasakawa, C.; Ropeleski, M.J.; Peek, R.M.; Jones, N.L. Helicobacter pylori cytotoxin-associated gene A activates the signal transducer and activator of transcription 3 pathway in vitro and in vivo. Cancer Res. 2009, 69, 632-639. [CrossRef] [PubMed]

72. Kuijl, C.; Savage, N.D.; Marsman, M.; Tuin, A.W.; Janssen, L.; Egan, D.A.; Ketema, M.; van den Nieuwendijk, R.; van den Eeden, S.J.; Geluk, A.; et al. Intracellular bacterial growth is controlled by a kinase network around PKB/AKT1. Nature 2007, 450, 725-730. [CrossRef] [PubMed]

73. Matozaki, T.; Murata, Y.; Saito, Y.; Okazawa, H.; Ohnishi, H. Protein tyrosine phosphatase SHP-2: A proto-oncogene product that promotes Ras activation. Cancer Sci. 2009, 100, 1786-1793. [CrossRef] [PubMed]

74. Ding, S.Z.; Minohara, Y.; Fan, X.J.; Wang, J.; Reyes, V.E.; Patel, J.; Dirden-Kramer, B.; Boldogh, I.; Ernst, P.B.; Crowe, S.E. Helicobacter pylori infection induces oxidative stress and programmed cell death in human gastric epithelial cells. Infect. Immun. 2007, 75, 4030-4039. [CrossRef] [PubMed] 
75. Wada, Y.; Takemura, K.; Tummala, P.; Uchida, K.; Kitagaki, K.; Furukawa, A.; Ishige, Y.; Ito, T.; Hara, Y.; Suzuki, T.; et al. Helicobacter pylori induces somatic mutations in TP53 via overexpression of CHAC1 in infected gastric epithelial cells . FEBS Open Bio 2018, 8, 671-679. [CrossRef]

76. Belkaid, Y.; Hand, T.W. Role of the microbiota in immunity and inflammation. Cell 2014, 157, $121-141$. [CrossRef]

77. Goodwin, A.C.; Destefano Shields, C.E.; Wu, S.; Huso, D.L.; Wu, X.; Murray-Stewart, T.R.; Hacker-Prietz, A.; Rabizadeh, S.; Woster, P.M.; Sears, C.L.; et al. Polyamine catabolism contributes to enterotoxigenic Bacteroides fragilis-induced colon tumorigenesis. Proc. Natl. Acad. Sci. USA 2011, 108, 15354-15359. [CrossRef]

78. Chaturvedi, R.; Asim, M.; Romero-Gallo, J.; Barry, D.P.; Hoge, S.; de Sablet, T.; Delgado, A.G.; Wroblewski, L.E.; Piazuelo, M.B.; Yan, F.; et al. Spermine oxidase mediates the gastric cancer risk associated with Helicobacter pylori CagA. Gastroenterology 2011, 141, 1696-1708. [CrossRef]

79. Huycke, M.M.; Moore, D.; Joyce, W.; Wise, P.; Shepard, L.; Kotake, Y.; Gilmore, M.S. Extracellular superoxide production by Enterococcus faecalis requires demethylmenaquinone and is attenuated by functional terminal quinol oxidases. Mol. Microbiol. 2001, 42, 729-740. [CrossRef]

80. Gur, C.; Ibrahim, Y.; Isaacson, B.; Yamin, R.; Abed, J.; Gamliel, M.; Enk, J.; Bar-On, Y.; Stanietsky-Kaynan, N.; Coppenhagen-Glazer, S.; et al. Binding of the Fap2 protein of Fusobacterium nucleatum to human inhibitory receptor TIGIT protects tumors from immune cell attack. Immunity 2015, 42, 344-355. [CrossRef]

81. Plottel, C.S.; Blaser, M.J. Microbiome and malignancy. Cell Host Microbe 2011, 10, 324-335. [CrossRef]

82. Doisneau-Sixou, S.F.; Sergio, C.M.; Carroll, J.S.; Hui, R.; Musgrove, E.A.; Sutherland, R.L. Estrogen and antiestrogen regulation of cell cycle progression in breast cancer cells. Endocr. Relat. Cancer 2003, 10, $179-186$. [CrossRef]

83. Fernández, M.F.; Reina-Pérez, I.; Astorga, J.M.; Rodríguez-Carrillo, A.; Plaza-Díaz, J.; Fontana, L. Breast Cancer and Its Relationship with the Microbiota. Int. J. Environ. Res. Public Health 2018, 15, 1747. [CrossRef]

84. Kilkkinen, A.; Rissanen, H.; Klaukka, T.; Pukkala, E.; Heliövaara, M.; Huovinen, P.; Männistö, S.; Aromaa, A.; Knekt, P. Antibiotic use predicts an increased risk of cancer. Int. J. Cancer 2008, 123, 2152-2155. [CrossRef]

85. Conlon, M.A.; Bird, A.R. The impact of diet and lifestyle on gut microbiota and human health. Nutrients 2014, 7, 17-44. [CrossRef]

86. Lee, C.S.; Ryan, E.J.; Doherty, G.A. Gastro-intestinal toxicity of chemotherapeutics in colorectal cancer: The role of inflammation. World J. Gastroenterol. 2014, 20, 3751-3761. [CrossRef]

87. Goldin, B.R.; Gualtieri, L.J.; Moore, R.P. The effect of Lactobacillus GG on the initiation and promotion of DMH-induced intestinal tumors in the rat. Nutr. Cancer 1996, 25, 197-204. [CrossRef]

88. Khailova, L.; Baird, C.H.; Rush, A.A.; Barnes, C.; Wischmeyer, P.E. Lactobacillus rhamnosus GG treatment improves intestinal permeability and modulates inflammatory response and homeostasis of spleen and colon in experimental model of Pseudomonas aeruginosa pneumonia. Clin. Nutr. 2017, 36, 1549-1557. [CrossRef]

89. Wang, Y.; Liu, L.; Moore, D.J.; Shen, X.; Peek, R.M.; Acra, S.A.; Li, H.; Ren, X.; Polk, D.B.; Yan, F. An LGG-derived protein promotes IgA production through upregulation of APRIL expression in intestinal epithelial cells. Mucosal Immunol. 2017, 10, 373-384. [CrossRef]

90. Fong, F.L.; Kirjavainen, P.V.; El-Nezami, H. Immunomodulation of Lactobacillus rhamnosus GG (LGG)-derived soluble factors on antigen-presenting cells of healthy blood donors. Sci. Rep. 2016, 6, 22845. [CrossRef]

91. Chang, C.W.; Liu, C.Y.; Lee, H.C.; Huang, Y.H.; Li, L.H.; Chiau, J.C.; Wang, T.E.; Chu, C.H.; Shih, S.C.; Tsai, T.H.; et al. Variety. Front. Microbiol. 2018, 9, 983. [CrossRef]

92. Riehl, T.E.; Alvarado, D.; Ee, X.; Zuckerman, A.; Foster, L.; Kapoor, V.; Thotala, D.; Ciorba, M.A.; Stenson, W.F. GG protects the intestinal epithelium from radiation injury through release of lipoteichoic acid, macrophage activation and the migration of mesenchymal stem cells. Gut 2018. [CrossRef]

93. Zhang, W.; Zhu, Y.H.; Yang, G.Y.; Liu, X.; Xia, B.; Hu, X.; Su, J.H.; Wang, J.F. GG Affects Microbiota and Suppresses Autophagy in the Intestines of Pigs Challenged with. Front. Microbiol. 2017, 8, 2705. [CrossRef]

94. Banna, G.L.; Torino, F.; Marletta, F.; Santagati, M.; Salemi, R.; Cannarozzo, E.; Falzone, L.; Ferraù, F.; Libra, M. GG: An Overview to Explore the Rationale of Its Use in Cancer. Front. Pharmacol. 2017, 8, 603. [CrossRef]

95. Gianotti, L.; Morelli, L.; Galbiati, F.; Rocchetti, S.; Coppola, S.; Beneduce, A.; Gilardini, C.; Zonenschain, D.; Nespoli, A.; Braga, M. A randomized double-blind trial on perioperative administration of probiotics in colorectal cancer patients. World J. Gastroenterol. 2010, 16, 167-175. [CrossRef]

96. Demers, M.; Dagnault, A.; Desjardins, J. A randomized double-blind controlled trial: Impact of probiotics on diarrhea in patients treated with pelvic radiation. Clin. Nutr. 2014, 33, 761-767. [CrossRef] 
97. Mego, M.; Chovanec, J.; Vochyanova-Andrezalova, I.; Konkolovsky, P.; Mikulova, M.; Reckova, M.; Miskovska, V.; Bystricky, B.; Beniak, J.; Medvecova, L.; et al. Prevention of irinotecan induced diarrhea by probiotics: A randomized double blind, placebo controlled pilot study. Complement Ther. Med. 2015, 23, 356-362. [CrossRef]

98. Theodoropoulos, G.E.; Memos, N.A.; Peitsidou, K.; Karantanos, T.; Spyropoulos, B.G.; Zografos, G. Synbiotics and gastrointestinal function-related quality of life after elective colorectal cancer resection. Ann. Gastroenterol. 2016, 29, 56-62.

99. Consoli, M.L.; da Silva, R.S.; Nicoli, J.R.; Bruña-Romero, O.; da Silva, R.G.; de Vasconcelos Generoso, S.; Correia, M.I. Randomized Clinical Trial: Impact of Oral Administration of Saccharomyces boulardii on Gene Expression of Intestinal Cytokines in Patients Undergoing Colon Resection. JPEN J. Parenter. Enter. Nutr. 2016, 40, 1114-1121. [CrossRef]

100. Hibberd, A.A.; Lyra, A.; Ouwehand, A.C.; Rolny, P.; Lindegren, H.; Cedgård, L.; Wettergren, Y. Intestinal microbiota is altered in patients with colon cancer and modified by probiotic intervention. BMJ Open Gastroenterol. 2017, 4, e000145. [CrossRef]

101. Flesch, A.T.; Tonial, S.T.; Contu, P.C.; Damin, D.C. Perioperative synbiotics administration decreases postoperative infections in patients with colorectal cancer: A randomized, double-blind clinical trial. Rev. Col. Bras. Cir. 2017, 44, 567-573. [CrossRef]

102. Orlando, A.; Linsalata, M.; Russo, F. Antiproliferative effects on colon adenocarcinoma cells induced by co-administration of vitamin K1 and Lactobacillus rhamnosus GG. Int. J. Oncol. 2016, 48, 2629-2638. [CrossRef]

103. Nouri, Z.; Karami, F.; Neyazi, N.; Modarressi, M.H.; Karimi, R.; Khorramizadeh, M.R.; Taheri, B.; Motevaseli, E. Dual Anti-Metastatic and Anti-Proliferative Activity Assessment of Two Probiotics on HeLa and HT-29 Cell Lines. Cell J. 2016, 18, 127-134.

104. Zhao, B.B.; Meng, J.; Zhang, Q.X.; Kang, T.T.; Lu, R.R. Protective effect of surface layer proteins isolated from four Lactobacillus strains on hydrogen-peroxide-induced HT-29 cells oxidative stress. Int. J. Biol. Macromol. 2017, 102, 76-83. [CrossRef]

105. Behzadi, E.; Mahmoodzadeh Hosseini, H.; Imani Fooladi, A.A. The inhibitory impacts of Lactobacillus rhamnosus GG-derived extracellular vesicles on the growth of hepatic cancer cells. Microb. Pathog. 2017, 110, 1-6. [CrossRef]

106. Cheng, Z.; Xu, H.; Wang, X.; Liu, Z. Lactobacillus raises in vitro anticancer effect of geniposide in HSC-3 human oral squamous cell carcinoma cells. Exp. Ther. Med. 2017, 14, 4586-4594. [CrossRef]

107. Taherian-Esfahani, Z.; Abedin-Do, A.; Nouri, Z.; Mirfakhraie, R.; Ghafouri-Fard, S.; Motevaseli, E. Differentially Modulate mTOR and WNT/ $\beta$-Catenin Pathways in Different Cancer Cell Lines. Iran J. Cancer Prev. 2016, 9, e5369. [CrossRef]

108. Ni, Y.; Wong, V.H.; Tai, W.C.; Li, J.; Wong, W.Y.; Lee, M.M.; Fong, F.L.; El-Nezami, H.; Panagiotou, G. A metagenomic study of the preventive effect of Lactobacillus rhamnosus GG on intestinal polyp formation in APC. J. Appl. Microbiol. 2017, 122, 770-784. [CrossRef]

109. Mendes, M.C.S.; Paulino, D.S.; Brambilla, S.R.; Camargo, J.A.; Persinoti, G.F.; Carvalheira, J.B.C. Microbiota modification by probiotic supplementation reduces colitis associated colon cancer in mice. World J. Gastroenterol. 2018, 24, 1995-2008. [CrossRef]

110. Gamallat, Y.; Meyiah, A.; Kuugbee, E.D.; Hago, A.M.; Chiwala, G.; Awadasseid, A.; Bamba, D.; Zhang, X.; Shang, X.; Luo, F.; et al. Lactobacillus rhamnosus induced epithelial cell apoptosis, ameliorates inflammation and prevents colon cancer development in an animal model. Biomed. Pharmacother. 2016, 83, 536-541. [CrossRef]

111. Cai, S.; Kandasamy, M.; Rahmat, J.N.; Tham, S.M.; Bay, B.H.; Lee, Y.K.; Mahendran, R. Lactobacillus rhamnosus GG Activation of Dendritic Cells and Neutrophils Depends on the Dose and Time of Exposure. J. Immunol. Res. 2016, 2016, 7402760. [CrossRef]

112. Suzuki, C.; Aoki-Yoshida, A.; Aoki, R.; Sasaki, K.; Takayama, Y.; Mizumachi, K. The distinct effects of orally administered Lactobacillus rhamnosus GG and Lactococcus lactis subsp. lactis C59 on gene expression in the murine small intestine. PLoS ONE 2017, 12, e0188985. [CrossRef] [PubMed]

113. Yu, J.; Zhu, Y.H.; Yang, G.Y.; Zhang, W.; Zhou, D.; Su, J.H.; Wang, J.F. Anti-inflammatory capacity of Lactobacillus rhamnosus GG in monophasic variant Salmonella infected piglets is correlated with impeding NLRP6-mediated host inflammatory responses. Vet. Microbiol. 2017, 210, 91-100. [CrossRef] 
114. Taranu, I.; Marin, D.E.; Braicu, C.; Pistol, G.C.; Sorescu, I.; Pruteanu, L.L.; Berindan Neagoe, I.; Vodnar, D.C. In Vitro Transcriptome Response to a Mixture of Lactobacilli Strains in Intestinal Porcine Epithelial Cell Line. Int. J. Mol. Sci. 2018, 19, 1923. [CrossRef] [PubMed]

115. Uribe, G.; Villéger, R.; Bressollier, P.; Dillard, R.N.; Worthley, D.L.; Wang, T.C.; Powell, D.W.; Urdaci, M.C.; Pinchuk, I.V. Lactobacillus rhamnosus GG increases COX-2 expression and PGE. Cell. Microbiol. 2018, 20, e12871. [CrossRef]

116. Levy, M.; Thaiss, C.A.; Katz, M.N.; Suez, J.; Elinav, E. Inflammasomes and the microbiota-partners in the preservation of mucosal homeostasis. Semin. Immunopathol. 2015, 37, 39-46. [CrossRef] [PubMed]

117. Franchi, L.; Eigenbrod, T.; Muñoz-Planillo, R.; Nuñez, G. The inflammasome: A caspase-1-activation platform that regulates immune responses and disease pathogenesis. Nat. Immunol. 2009, 10, 241-247. [CrossRef] [PubMed]

118. Zitvogel, L.; Kepp, O.; Galluzzi, L.; Kroemer, G. Inflammasomes in carcinogenesis and anticancer immune responses. Nat. Immunol. 2012, 13, 343-351. [CrossRef] [PubMed]

119. Kantono, M.; Guo, B. Inflammasomes and Cancer: The Dynamic Role of the Inflammasome in Tumor Development. Front. Immunol. 2017, 8, 1132. [CrossRef]

120. Zaki, M.H.; Lamkanfi, M.; Kanneganti, T.D. The NLRP3 inflammasome: Contributions to intestinal homeostasis. Trends Immunol. 2011, 32, 171-179. [CrossRef] [PubMed]

121. Allen, I.C.; TeKippe, E.M.; Woodford, R.M.; Uronis, J.M.; Holl, E.K.; Rogers, A.B.; Herfarth, H.H.; Jobin, C.; Ting, J.P. The NLRP3 inflammasome functions as a negative regulator of tumorigenesis during colitis-associated cancer. J. Exp. Med. 2010, 207, 1045-1056. [CrossRef] [PubMed]

122. Hu, B.; Elinav, E.; Huber, S.; Booth, C.J.; Strowig, T.; Jin, C.; Eisenbarth, S.C.; Flavell, R.A. Inflammation-induced tumorigenesis in the colon is regulated by caspase-1 and NLRC4. Proc. Natl. Acad. Sci. USA 2010, 107, 21635-21640. [CrossRef] [PubMed]

123. Dupaul-Chicoine, J.; Yeretssian, G.; Doiron, K.; Bergstrom, K.S.; McIntire, C.R.; LeBlanc, P.M.; Meunier, C.; Turbide, C.; Gros, P.; Beauchemin, N.; et al. Control of intestinal homeostasis, colitis, and colitis-associated colorectal cancer by the inflammatory caspases. Immunity 2010, 32, 367-378. [CrossRef]

124. Zaki, M.H.; Vogel, P.; Body-Malapel, M.; Lamkanfi, M.; Kanneganti, T.D. IL-18 production downstream of the NLRP3 inflammasome confers protection against colorectal tumor formation. J. Immunol. 2010, 185, 4912-4920. [CrossRef] [PubMed]

125. Salcedo, R.; Worschech, A.; Cardone, M.; Jones, Y.; Gyulai, Z.; Dai, R.M.; Wang, E.; Ma, W.; Haines, D.; O'hUigin, C.; et al. MyD88-mediated signaling prevents development of adenocarcinomas of the colon: Role of interleukin 18. J. Exp. Med. 2010, 207, 1625-1636. [CrossRef]

126. McLoed, A.G.; Sherrill, T.P.; Cheng, D.S.; Han, W.; Saxon, J.A.; Gleaves, L.A.; Wu, P.; Polosukhin, V.V.; Karin, M.; Yull, F.E.; et al. Neutrophil-Derived IL-1 $\beta$ Impairs the Efficacy of NF-кB Inhibitors against Lung Cancer. Cell Rep. 2016, 16, 120-132. [CrossRef] [PubMed]

127. Okamoto, M.; Liu, W.; Luo, Y.; Tanaka, A.; Cai, X.; Norris, D.A.; Dinarello, C.A.; Fujita, M. Constitutively active inflammasome in human melanoma cells mediating autoinflammation via caspase-1 processing and secretion of interleukin-1beta. J. Biol. Chem. 2010, 285, 6477-6488. [CrossRef]

128. Zhong, F.L.; Mamaï, O.; Sborgi, L.; Boussofara, L.; Hopkins, R.; Robinson, K.; Szeverényi, I.; Takeichi, T.; Balaji, R.; Lau, A.; et al. Germline NLRP1 Mutations Cause Skin Inflammatory and Cancer Susceptibility Syndromes via Inflammasome Activation. Cell 2016, 167, 187-202. [CrossRef]

129. Kolb, R.; Phan, L.; Borcherding, N.; Liu, Y.; Yuan, F.; Janowski, A.M.; Xie, Q.; Markan, K.R.; Li, W.; Potthoff, M.J.; et al. Obesity-associated NLRC4 inflammasome activation drives breast cancer progression. Nat. Commun. 2016, 7, 13007. [CrossRef]

130. Daley, D.; Mani, V.R.; Mohan, N.; Akkad, N.; Pandian, G.S.D.B.; Savadkar, S.; Lee, K.B.; Torres-Hernandez, A.; Aykut, B.; Diskin, B.; et al. NLRP3 signaling drives macrophage-induced adaptive immune suppression in pancreatic carcinoma. J. Exp. Med. 2017, 214, 1711-1724. [CrossRef]

131. Chen, G.Y.; Liu, M.; Wang, F.; Bertin, J.; Núñez, G. A functional role for NLRP6 in intestinal inflammation and tumorigenesis. J. Immunol. 2011, 186, 7187-7194. [CrossRef] [PubMed]

132. Williams, T.M.; Leeth, R.A.; Rothschild, D.E.; Coutermarsh-Ott, S.L.; McDaniel, D.K.; Simmons, A.E.; Heid, B.; Cecere, T.E.; Allen, I.C. The NLRP1 inflammasome attenuates colitis and colitis-associated tumorigenesis. J. Immunol. 2015, 194, 3369-3380. [CrossRef] [PubMed] 
133. Zaki, M.H.; Boyd, K.L.; Vogel, P.; Kastan, M.B.; Lamkanfi, M.; Kanneganti, T.D. The NLRP3 inflammasome protects against loss of epithelial integrity and mortality during experimental colitis. Immunity 2010, 32, 379-391. [CrossRef] [PubMed]

134. Henao-Mejia, J.; Elinav, E.; Jin, C.; Hao, L.; Mehal, W.Z.; Strowig, T.; Thaiss, C.A.; Kau, A.L.; Eisenbarth, S.C.; Jurczak, M.J.; et al. Inflammasome-mediated dysbiosis regulates progression of NAFLD and obesity. Nature 2012, 482, 179-185. [CrossRef] [PubMed]

135. Elinav, E.; Strowig, T.; Kau, A.L.; Henao-Mejia, J.; Thaiss, C.A.; Booth, C.J.; Peaper, D.R.; Bertin, J.; Eisenbarth, S.C.; Gordon, J.I.; et al. NLRP6 inflammasome regulates colonic microbial ecology and risk for colitis. Cell 2011, 145, 745-757. [CrossRef]

136. Levy, M.; Thaiss, C.A.; Zeevi, D.; Dohnalová, L.; Zilberman-Schapira, G.; Mahdi, J.A.; David, E.; Savidor, A.; Korem, T.; Herzig, Y.; et al. Microbiota-Modulated Metabolites Shape the Intestinal Microenvironment by Regulating NLRP6 Inflammasome Signaling. Cell 2015, 163, 1428-1443. [CrossRef] [PubMed]

137. Levy, M.; Shapiro, H.; Thaiss, C.A.; Elinav, E. NLRP6: A Multifaceted Innate Immune Sensor. Trends Immunol. 2017, 38, 248-260. [CrossRef]

138. Miettinen, M.; Pietilä, T.E.; Kekkonen, R.A.; Kankainen, M.; Latvala, S.; Pirhonen, J.; Österlund, P.; Korpela, R.; Julkunen, I. Nonpathogenic Lactobacillus rhamnosus activates the inflammasome and antiviral responses in human macrophages. Gut Microbes 2012, 3, 510-522. [CrossRef]

139. Elinav, E.; Henao-Mejia, J.; Strowig, T.; Flavell, R. NLRP6 and Dysbiosis: Avoiding the Luring Attraction of Over-Simplification. Immunity 2018, 48, 603-604. [CrossRef]

140. Dy, G.K.; Adjei, A.A. Understanding, recognizing, and managing toxicities of targeted anticancer therapies. CA Cancer J. Clin. 2013, 63, 249-279. [CrossRef]

141. Vogelstein, B.; Papadopoulos, N.; Velculescu, V.E.; Zhou, S.; Diaz, L.A.; Kinzler, K.W. Cancer genome landscapes. Science 2013, 339, 1546-1558. [CrossRef] [PubMed]

142. Bhang, H.E.; Ruddy, D.A.; Krishnamurthy Radhakrishna, V.; Caushi, J.X.; Zhao, R.; Hims, M.M.; Singh, A.P.; Kao, I.; Rakiec, D.; Shaw, P.; et al. Studying clonal dynamics in response to cancer therapy using high-complexity barcoding. Nat. Med. 2015, 21, 440-448. [CrossRef] [PubMed]

143. Kloor, M.; von Knebel Doeberitz, M. The Immune Biology of Microsatellite-Unstable Cancer. Trends Cancer 2016, 2, 121-133. [CrossRef] [PubMed]

144. Carter, S.L.; Eklund, A.C.; Kohane, I.S.; Harris, L.N.; Szallasi, Z. A signature of chromosomal instability inferred from gene expression profiles predicts clinical outcome in multiple human cancers. Nat. Genet. 2006, 38, 1043-1048. [CrossRef]

145. Dagogo-Jack, I.; Shaw, A.T. Tumour heterogeneity and resistance to cancer therapies. Nat. Rev. Clin. Oncol. 2018, 15, 81-94. [CrossRef] [PubMed]

146. McGranahan, N.; Swanton, C. Biological and therapeutic impact of intratumor heterogeneity in cancer evolution. Cancer Cell 2015, 27, 15-26. [CrossRef] [PubMed]

147. Thorsson, V.; Gibbs, D.L.; Brown, S.D.; Wolf, D.; Bortone, D.S.; Ou Yang, T.H.; Porta-Pardo, E.; Gao, G.F.; Plaisier, C.L.; Eddy, J.A.; et al. The Immune Landscape of Cancer. Immunity 2018, 48, 812-830. [CrossRef] [PubMed]

148. Emens, L.A.; Ascierto, P.A.; Darcy, P.K.; Demaria, S.; Eggermont, A.M.M.; Redmond, W.L.; Seliger, B.; Marincola, F.M. Cancer immunotherapy: Opportunities and challenges in the rapidly evolving clinical landscape. Eur. J. Cancer 2017, 81, 116-129. [CrossRef]

149. Toh, H.C. Cancer immunotherapy-the end of the beginning. Chin. Clin. Oncol. 2018, 7, 12. [CrossRef]

150. Roy, S.; Trinchieri, G. Microbiota: A key orchestrator of cancer therapy. Nat. Rev. Cancer 2017, 17, $271-285$. [CrossRef]

151. Nayak, R.R.; Turnbaugh, P.J. Mirror, mirror on the wall: Which microbiomes will help heal them all? BMC Med. 2016, 14, 72. [CrossRef]

152. Fessler, J.L.; Gajewski, T.F. The Microbiota: A New Variable Impacting Cancer Treatment Outcomes. Clin. Cancer Res. 2017, 23, 3229-3231. [CrossRef] [PubMed]

153. McCarthy, E.F. The toxins of William B. Coley and the treatment of bone and soft-tissue sarcomas. IOWA Orthop. J. 2006, 26, 154-158. [PubMed]

154. Nauts, H.C.; Swift, W.E.; Coley, B.L. The treatment of malignant tumors by bacterial toxins as developed by the late William B. Coley, M.D., reviewed in the light of modern research. Cancer Res. 1946, 6, 205-216. [PubMed] 
155. Zbar, B.; Bernstein, I.; Tanaka, T.; Rapp, H.J. Tumor immunity produced by the intradermal inoculation of living tumor cells and living Mycobacterium bovis (strain BCG). Science 1970, 170, 1217-1218. [CrossRef] [PubMed]

156. Aso, Y.; Akazan, H. Prophylactic effect of a Lactobacillus casei preparation on the recurrence of superficial bladder cancer. BLP Study Group. Urol. Int. 1992, 49, 125-129. [CrossRef]

157. Hoesl, C.E.; Altwein, J.E. The probiotic approach: An alternative treatment option in urology. Eur. Urol. 2005, 47, 288-296. [CrossRef] [PubMed]

158. Felgner, S.; Kocijancic, D.; Frahm, M.; Weiss, S. Bacteria in Cancer Therapy: Renaissance of an Old Concept. Int. J. Microbiol. 2016, 2016, 8451728. [CrossRef]

159. Stebbing, J.; Dalgleish, A.; Gifford-Moore, A.; Martin, A.; Gleeson, C.; Wilson, G.; Brunet, L.R.; Grange, J.; Mudan, S. An intra-patient placebo-controlled phase I trial to evaluate the safety and tolerability of intradermal IMM-101 in melanoma. Ann. Oncol. 2012, 23, 1314-1319. [CrossRef]

160. Dalgleish, A.G.; Stebbing, J.; Adamson, D.J.; Arif, S.S.; Bidoli, P.; Chang, D.; Cheeseman, S.; Diaz-Beveridge, R.; Fernandez-Martos, C.; Glynne-Jones, R.; et al. Randomised, open-label, phase II study of gemcitabine with and without IMM-101 for advanced pancreatic cancer. Br. J. Cancer 2016, 115, 789-796. [CrossRef]

161. Toso, J.F.; Gill, V.J.; Hwu, P.; Marincola, F.M.; Restifo, N.P.; Schwartzentruber, D.J.; Sherry, R.M.; Topalian, S.L.; Yang, J.C.; Stock, F.; et al. Phase I study of the intravenous administration of attenuated Salmonella typhimurium to patients with metastatic melanoma. J. Clin. Oncol. 2002, 20, 142-152. [CrossRef] [PubMed]

162. Nemunaitis, J.; Cunningham, C.; Senzer, N.; Kuhn, J.; Cramm, J.; Litz, C.; Cavagnolo, R.; Cahill, A.; Clairmont, C.; Sznol, M. Pilot trial of genetically modified, attenuated Salmonella expressing the E. coli cytosine deaminase gene in refractory cancer patients. Cancer Gene Ther. 2003, 10, 737-744. [CrossRef] [PubMed]

163. Kramer, M.G.; Masner, M.; Ferreira, F.A.; Hoffman, R.M. Bacterial Therapy of Cancer: Promises, Limitations, and Insights for Future Directions. Front. Microbiol. 2018, 9, 16. [CrossRef] [PubMed]

164. Schwabe, R.F.; Jobin, C. The microbiome and cancer. Nat. Rev. Cancer 2013, 13, 800-812. [CrossRef] [PubMed]

165. Iida, N.; Dzutsev, A.; Stewart, C.A.; Smith, L.; Bouladoux, N.; Weingarten, R.A.; Molina, D.A.; Salcedo, R.; Back, T.; Cramer, S.; et al. Commensal bacteria control cancer response to therapy by modulating the tumor microenvironment. Science 2013, 342, 967-970. [CrossRef]

166. Gui, Q.F.; Lu, H.F.; Zhang, C.X.; Xu, Z.R.; Yang, Y.H. Well-balanced commensal microbiota contributes to anti-cancer response in a lung cancer mouse model. Genet. Mol. Res. 2015, 14, 5642-5651. [CrossRef]

167. Viaud, S.; Saccheri, F.; Mignot, G.; Yamazaki, T.; Daillère, R.; Hannani, D.; Enot, D.P.; Pfirschke, C.; Engblom, C.; Pittet, M.J.; et al. The intestinal microbiota modulates the anticancer immune effects of cyclophosphamide. Science 2013, 342, 971-976. [CrossRef]

168. Daillère, R.; Vétizou, M.; Waldschmitt, N.; Yamazaki, T.; Isnard, C.; Poirier-Colame, V.; Duong, C.P.M.; Flament, C.; Lepage, P.; Roberti, M.P.; et al. Enterococcus hirae and Barnesiella intestinihominis Facilitate Cyclophosphamide-Induced Therapeutic Immunomodulatory Effects. Immunity 2016, 45, 931-943. [CrossRef]

169. Jahrsdörfer, B.; Weiner, G.J. CpG oligodeoxynucleotides as immunotherapy in cancer. Update Cancer Ther. 2008, 3, 27-32. [CrossRef]

170. Routy, B.; Le Chatelier, E.; Derosa, L.; Duong, C.P.M.; Alou, M.T.; Daillère, R.; Fluckiger, A.; Messaoudene, M.; Rauber, C.; Roberti, M.P.; et al. Gut microbiome influences efficacy of PD-1-based immunotherapy against epithelial tumors. Science 2018, 359, 91-97. [CrossRef]

171. Gopalakrishnan, V.; Spencer, C.N.; Nezi, L.; Reuben, A.; Andrews, M.C.; Karpinets, T.V.; Prieto, P.A.; Vicente, D.; Hoffman, K.; Wei, S.C.; et al. Gut microbiome modulates response to anti-PD-1 immunotherapy in melanoma patients. Science 2018, 359, 97-103. [CrossRef]

172. Matson, V.; Fessler, J.; Bao, R.; Chongsuwat, T.; Zha, Y.; Alegre, M.L.; Luke, J.J.; Gajewski, T.F. The commensal microbiome is associated with anti-PD-1 efficacy in metastatic melanoma patients. Science 2018, 359, 104-108. [CrossRef] [PubMed]

173. Chen, Q.; Wang, C.; Chen, G.; Hu, Q.; Gu, Z. Delivery Strategies for Immune Checkpoint Blockade. Adv. Healthc. Mater. 2018, 7, e1800424. [CrossRef] [PubMed]

174. Buchbinder, E.I.; Desai, A. CTLA-4 and PD-1 Pathways: Similarities, Differences, and Implications of Their Inhibition. Am. J. Clin. Oncol. 2016, 39, 98-106. [CrossRef] [PubMed] 
175. Vétizou, M.; Pitt, J.M.; Daillère, R.; Lepage, P.; Waldschmitt, N.; Flament, C.; Rusakiewicz, S.; Routy, B.; Roberti, M.P.; Duong, C.P.; et al. Anticancer immunotherapy by CTLA-4 blockade relies on the gut microbiota. Science 2015, 350, 1079-1084. [CrossRef] [PubMed]

176. Sivan, A.; Corrales, L.; Hubert, N.; Williams, J.B.; Aquino-Michaels, K.; Earley, Z.M.; Benyamin, F.W.; Lei, Y.M.; Jabri, B.; Alegre, M.L.; et al. Commensal Bifidobacterium promotes antitumor immunity and facilitates anti-PD-L1 efficacy. Science 2015, 350, 1084-1089. [CrossRef] [PubMed]

177. Larkin, J.; Hodi, F.S.; Wolchok, J.D. Combined Nivolumab and Ipilimumab or Monotherapy in Untreated Melanoma. N. Engl. J. Med. 2015, 373, 1270-1271. [CrossRef] [PubMed]

178. Chaput, N.; Lepage, P.; Coutzac, C.; Soularue, E.; Le Roux, K.; Monot, C.; Boselli, L.; Routier, E.; Cassard, L.; Collins, M.; et al. Baseline gut microbiota predicts clinical response and colitis in metastatic melanoma patients treated with ipilimumab. Ann. Oncol. 2017, 28, 1368-1379. [CrossRef]

179. Frankel, A.E.; Coughlin, L.A.; Kim, J.; Froehlich, T.W.; Xie, Y.; Frenkel, E.P.; Koh, A.Y. Metagenomic Shotgun Sequencing and Unbiased Metabolomic Profiling Identify Specific Human Gut Microbiota and Metabolites Associated with Immune Checkpoint Therapy Efficacy in Melanoma Patients. Neoplasia 2017, 19, 848-855. [CrossRef]

180. Bajic, J.E.; Johnston, I.N.; Howarth, G.S.; Hutchinson, M.R. From the Bottom-Up: Chemotherapy and Gut-Brain Axis Dysregulation. Front. Behav. Neurosci. 2018, 12, 104. [CrossRef]

181. Scaife, J.E.; Barnett, G.C.; Noble, D.J.; Jena, R.; Thomas, S.J.; West, C.M.; Burnet, N.G. Exploiting biological and physical determinants of radiotherapy toxicity to individualize treatment. Br. J. Radiol. 2015, 88, 20150172. [CrossRef] [PubMed]

182. Griggs, J.J. Reducing the toxicity of anticancer therapy: New strategies. Leuk. Res. 1998, 22 (Suppl. 1), S27-S33. [CrossRef]

183. Samaan, M.A.; Pavlidis, P.; Papa, S.; Powell, N.; Irving, P.M. Gastrointestinal toxicity of immune checkpoint inhibitors: From mechanisms to management. Nat. Rev. Gastroenterol. Hepatol. 2018, 15, 222-234. [CrossRef] [PubMed]

184. Dong, J.; Chen, H. Cardiotoxicity of Anticancer Therapeutics. Front. Cardiovasc. Med. 2018, 5, 9. [CrossRef] [PubMed]

185. Shahid, F.; Farooqui, Z.; Khan, F. Cisplatin-induced gastrointestinal toxicity: An update on possible mechanisms and on available gastroprotective strategies. Eur. J. Pharmacol. 2018, 827, 49-57. [CrossRef] [PubMed]

186. Lawrie, T.A.; Green, J.T.; Beresford, M.; Wedlake, L.; Burden, S.; Davidson, S.E.; Lal, S.; Henson, C.C.; Andreyev, H.J.N. Interventions to reduce acute and late adverse gastrointestinal effects of pelvic radiotherapy for primary pelvic cancers. Cochrane Database Syst. Rev. 2018, 1, CD012529. [CrossRef]

187. Alexander, J.L.; Wilson, I.D.; Teare, J.; Marchesi, J.R.; Nicholson, J.K.; Kinross, J.M. Gut microbiota modulation of chemotherapy efficacy and toxicity. Nat. Rev. Gastroenterol. Hepatol. 2017, 14, 356-365. [CrossRef]

188. Sokol, H.; Adolph, T.E. The microbiota: An underestimated actor in radiation-induced lesions? Gut 2018, 67, 1-2. [CrossRef]

189. Zitvogel, L.; Ma, Y.; Raoult, D.; Kroemer, G.; Gajewski, T.F. The microbiome in cancer immunotherapy: Diagnostic tools and therapeutic strategies. Science 2018, 359, 1366-1370. [CrossRef]

190. Vanderhoof, J.A.; Young, R. Probiotics in the United States. Clin. Infect. Dis. 2008, 46 (Suppl. 2), S67-S72; discussion S144-S151. [CrossRef]

191. Redman, M.G.; Ward, E.J.; Phillips, R.S. The efficacy and safety of probiotics in people with cancer: A systematic review. Ann. Oncol. 2014, 25, 1919-1929. [CrossRef]

192. Mego, M.; Holec, V.; Drgona, L.; Hainova, K.; Ciernikova, S.; Zajac, V. Probiotic bacteria in cancer patients undergoing chemotherapy and radiation therapy. Complement. Ther. Med. 2013, 21, 712-723. [CrossRef] [PubMed]

193. Peterson, D.E.; Boers-Doets, C.B.; Bensadoun, R.J.; Herrstedt, J.; Committee, E.G. Management of oral and gastrointestinal mucosal injury: ESMO Clinical Practice Guidelines for diagnosis, treatment, and follow-up. Ann. Oncol. 2015, 26 (Suppl. 5), v139-v151. [CrossRef] [PubMed]

194. Lalla, R.V.; Bowen, J.; Barasch, A.; Elting, L.; Epstein, J.; Keefe, D.M.; McGuire, D.B.; Migliorati, C.; Nicolatou-Galitis, O.; Peterson, D.E.; et al. MASCC/ISOO clinical practice guidelines for the management of mucositis secondary to cancer therapy. Cancer 2014, 120, 1453-1461. [CrossRef] [PubMed] 
195. van Nood, E.; Dijkgraaf, M.G.; Keller, J.J. Duodenal infusion of feces for recurrent Clostridium difficile. N. Engl. J. Med. 2013, 368, 2145. [CrossRef] [PubMed]

196. Khoruts, A.; Rank, K.M.; Newman, K.M.; Viskocil, K.; Vaughn, B.P.; Hamilton, M.J.; Sadowsky, M.J. Inflammatory Bowel Disease Affects the Outcome of Fecal Microbiota Transplantation for Recurrent Clostridium difficile Infection. Clin. Gastroenterol. Hepatol. 2016, 14, 1433-1438. [CrossRef] [PubMed]

197. Kakihana, K.; Fujioka, Y.; Suda, W.; Najima, Y.; Kuwata, G.; Sasajima, S.; Mimura, I.; Morita, H.; Sugiyama, D.; Nishikawa, H.; et al. Fecal microbiota transplantation for patients with steroid-resistant acute graft-versus-host disease of the gut. Blood 2016, 128, 2083-2088. [CrossRef]

198. Bel, S.; Elkis, Y.; Elifantz, H.; Koren, O.; Ben-Hamo, R.; Lerer-Goldshtein, T.; Rahimi, R.; Ben Horin, S.; Nyska, A.; Shpungin, S.; et al. Reprogrammed and transmissible intestinal microbiota confer diminished susceptibility to induced colitis in TMF ${ }^{-/-}$mice. Proc. Natl. Acad. Sci. USA 2014, 111, 4964-4969. [CrossRef]

199. Cohen, N.A.; Maharshak, N. Novel Indications for Fecal Microbial Transplantation: Update and Review of the Literature. Dig. Dis. Sci. 2017, 62, 1131-1145. [CrossRef]

(C) 2019 by the authors. Licensee MDPI, Basel, Switzerland. This article is an open access article distributed under the terms and conditions of the Creative Commons Attribution (CC BY) license (http:/ / creativecommons.org/licenses/by/4.0/). 